Spring 4-11-2021

\title{
Improving Antibiotic Prescribing for Acute Respiratory Illnesses
}

Laurinia Hunter

University of St. Augustine for Health Sciences, I.hunter@usa.edu

DOI: https://doi.org/10.46409/sr.AYWA2368

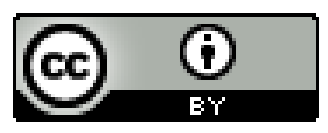

This work is licensed under a Creative Commons Attribution 4.0 License.

Follow this and additional works at: https://soar.usa.edu/scholprojects

Part of the Family Practice Nursing Commons, Pharmacy Administration, Policy and Regulation Commons, and the Respiratory Tract Diseases Commons

\section{Recommended Citation}

Hunter, L. (2021). Improving Antibiotic Prescribing for Acute Respiratory IIInesses. [Doctoral project, University of St Augustine for Health Sciences]. SOAR @ USA: Student Scholarly Projects Collection. https://doi.org/10.46409/sr.AYWA2368

This Scholarly Project is brought to you for free and open access by the Student Research at SOAR @ USA. It has been accepted for inclusion in Student Scholarly Projects by an authorized administrator of SOAR @ USA. For more information, please contact soar@usa.edu, erobinson@usa.edu. 
Improving Antibiotic Prescribing for Acute Respiratory Illnesses

Laurinia K. Hunter RN, MSN, FNP-BC

School of Nursing, University of St. Augustine for Health Sciences

This Manuscript Partially Fulfills the Requirements for the

Doctor of Nursing Practice Program and is Approved by:

Dr. Kathleen Farrell DNSc, RN

Dr. Mani Ghafouri DNP, MBA, CNP, RN

Approved: April 11, 2021 


\begin{abstract}
Practice Problem: Unwarranted antibiotic prescribing practices when treating acute respiratory illnesses contribute to the national health threat of antibiotic resistance.

PICOT: In a pediatric outpatient setting for patients ages 6-25 who have no documented uncontrolled comorbidities, presenting with an acute respiratory illness $(\mathrm{P})$, does provider utilization of clinical guidelines, and patient and (caregivers) utilization of educational pamphlets, to collectively develop a plan of care (I), compared to providers and patients who do not utilize such strategies $(\mathrm{C})$ result in a reduction in antibiotics prescribed for acute respiratory illnesses $(\mathrm{O})$ in a 6-week timeframe $(\mathrm{T})$ ?

Evidence: The evidence reviewed reported the utilization of clinical treatment guidelines accompanied with patient education, and the collaborative formation of the plan of care when treating acute respiratory illnesses, resulted in a modest or profound reduction in antibiotics prescribed.

Intervention: Provider usage of The Centers for Disease Control (CDC) clinical guidelines accompanied by patient education to collaboratively formulate the treatment plan for the management of patients presenting with acute respiratory illnesses.

Outcome: Antibiotic prescribing rates when managing acute respiratory illness declined from $82 \%$ baseline to $42 \%$ post-intervention.

Conclusion: Provider utilization of CDC clinical guidelines, with patient education to collectively formulate a management plan when treating acute respiratory illnesses resulted in a reduction in non-medically indicated antibiotic prescriptive practices.
\end{abstract}




\section{Improving Antibiotic Prescribing for Acute Respiratory Illnesses}

The Centers for Disease Control (CDC) identified that approximately 47 million unnecessary antibiotic prescriptions are written each year, which is estimated at $30 \%$ of all prescriptions given in an outpatient setting (CDC, 2013). These unwarranted prescription practices continue to be a great public health threat today (Sanchez et al., 2016). Although antibiotics are invaluable in eradicating many life-threatening bacterial infections, they become resistant and lose effectiveness primarily due to poor prescription practices (Srinivasan, 2017).

The purpose of this project was to review evidence and use the findings to develop a proposed practice change. The proposed practice change promoted antibiotic stewardship as a mechanism to decrease unnecessary antibiotic prescriptions when treating acute respiratory illnesses in an outpatient setting.

\section{Significance of the Practice Problem}

In 2013, the CDC recognized antibiotic resistance as a major threat to the country's health. According to the CDC (2020), antibiotic resistance remains a cause of death for over 35,000 people in the United States each year. Antibiotic resistance has also been associated with an estimated 2.8 million infections each year in the United States (CDC, 2020). The leading cause for these staggering numbers is the unnecessary prescribing of antibiotics when not medically indicated.

The CDC has emphasized the need to combat antimicrobial resistance. Since an estimated, $60 \%$ of all U.S. antibiotic prescriptions are received in an outpatient setting (Guillford et al., 2016), the outpatient setting would be a good place to start a practice change project. In fact, it is estimated that in the outpatient setting, enough antibiotics are prescribed that 5 out of 
every $6^{\text {th }}$ person in the nation could receive a course of antibiotics each year. This equates to approximately 835 prescriptions per 1,000 people (CDC, 2019). Interestingly, in Scandinavian countries prescription rates are more than $50 \%$ lower $(400$ per 1,000$)$, than the U.S. rate due to strict adherence to antibiotic stewardship practices (CDC, 2019).

A program of Antibiotic Stewardship is promoted by the CDC as being a possible solution for the current antibiotic resistance crisis. Antibiotic stewardship is defined as concerted efforts used to improve antibiotic prescriptive practices by clinicians, so that antibiotics are only prescribed and used when indicated (Sanchez et al., 2016).

A national quality measure, the Healthcare Effectiveness Data and Information Set (HEDIS) is a tool implemented to measure healthcare performance and utilized by many payers in the United States. Acute bronchitis, a diagnosis that is under the acute respiratory illness category, was added to the list of HEDIS in 2008. The goal set was not prescribing antibiotics for the treatment of acute bronchitis at a rate of $100 \%$. When this performance rating was measured in 2018, the results indicated only $35 \%$ compliance (NCQA, 2020). Evaluation of the effectiveness of antibiotic stewardship within the outpatient settings could lead to practice changes capable of improving the future landscape of microbial resistance in the U.S.

\section{PICOT Question}

In a pediatric outpatient setting for patients ages 6-25 who have no documented uncontrolled comorbidities, presenting with an acute respiratory illness $(\mathrm{P})$, does provider utilization of clinical guidelines, and patient(caregiver) utilization of educational pamphlets, to collectively develop a plan of care (I), compared to providers and patients who do not utilize such strategies $(\mathrm{C})$ result in a reduction in antibiotics prescribed for acute respiratory illnesses $(\mathrm{O})$ in a 6-week timeframe $(\mathrm{T})$ ? 


\section{Population}

The population consisted of clinic providers and all patients and caregivers ages 6-25 who presented to a pediatric outpatient setting with a chief complaint of an acute respiratory illness without a history of uncontrolled comorbidities.

\section{Intervention}

Clinical providers received pre- intervention surveys to evaluate their current attitude and beliefs about antibiotic stewardship and the use of clinical guidelines. Clinical providers then were trained on current evidence based clinical guidelines for the treatment of acute respiratory illnesses (Appendix A). Patient's and or caregivers of minors received the CDC sponsored pamphlet at registration that addresses the appropriateness of antibiotic use when treating acute respiratory illnesses, to review prior to seeing the provider (Appendix B). Posters were posted in each waiting and exam room that highlighted national clinical pathway guidelines when treating acute respiratory illnesses (Appendix C). Following the clinical evaluations, providers, patients, and caregivers collectively referenced both pamphlet and poster to discuss and evaluate the clinical appropriateness for the utilization of antibiotics in managing the patient's current illness. Evidence has shown when providers utilize clinical guidelines, and patients and caregivers receive educational material, the results have been mildly effective at decreasing unwarranted antibiotic prescribing (Guillford et al., 2016).

\section{Comparison}

Pre-intervention antibiotic prescribing rates were obtained by reviewing retrospective data. The retrospective data reviewed were of patients diagnosed with acute respiratory illness during the same timeframe (December-January) the year prior. A tally was used to identify how many antibiotics were prescribed for those patients diagnosed with acute respiratory illnesses. 
These pre-intervention numbers were then compared to post intervention numbers utilizing the electronic medical record (EMR) to identify if the intervention resulted in a reduction in antibiotics prescribed for acute respiratory illnesses. The Upper Respiratory Tract Antibiotic Tracking Tool was utilized to assist with auditing the data collected from the EMR (Appendix D). Past studies have indicated when patients were given educational material on the appropriateness of antibiotics for the treatment of acute respiratory illnesses, there was a mild reduction in the number of patients insisting on antibiotics for treatment (O’Sullivan et al., 2016). Other past studies have shown, providers familiar with national clinical guidelines for the treatment of acute respiratory illnesses, had a better understanding of the ineffectiveness and risk of prescribing antibiotics when they were not indicated, which resulted in a reduction in antibiotic prescribing rates (Barlam et al., 2016). Pre- and post-test surveys were compared to evaluate if there was a change in provider's attitudes and beliefs regarding antibiotic stewardship initiatives (Appendix E).

\section{Outcome}

The interventions of clinical provider's utilization of national clinical guidelines for the treatment of acute respiratory illnesses, accompanied by patient educational brochures, and clinical pathway posters, were projected to result in an overall reduction of unwarranted antibiotics being prescribed for acute respiratory ailments. An additional benefit was the family/patient and the provider collectively reviewed the materials together and formulated a plan of care. If the post intervention rate of antibiotic prescriptions was lower than the preintervention prescribing rates, then the intervention was judged to result in a clinically significant reduction in unwarranted antibiotics prescribed when treating acute respiratory illnesses. The outcome was measured by utilizing the EMR to calculate the average antibiotics prescribed in a 
specific six-week timeframe (December-January) the year prior to intervention compared to the average rate of antibiotics prescribed in the equivalent six-week timeframe of the current year post initiation of the intervention.

\section{Timing}

Forty-two days after the initiation of the practice change was the estimated timeline to see a reduction in previous prescribing trends and demonstrated compliance with using the guidelines in practice. Six weeks was considered a reasonable amount of time to see changes in prescribing trends, as it allowed adequate time for providers to adjust to the incorporation and utilization of the clinical guideline, patient education, and the new procedure of collectively discussing clinical findings and corroborating a plan of care with the patient.

\section{Framework and Change Theory}

One major focus for those working in the health care industry is the improvement and protection of the populations health (Meeker et al., 2016). Providers working in pediatric outpatient settings assisted with the fight against microbial resistance through utilizing clinical guidelines and educational material to collaboratively formulate an appropriate plan of care when treating acute respiratory illnesses. Educating patients/caregiver regarding the risk and misuse of antibiotics helped them take an active role in avoiding antibiotics when not indicated, which helped to decrease the risks of antimicrobial resistance in our healthcare system. Healthcare providers are an important source of influence when it comes to understanding and adapting health promoting behaviors. Utilizing clinical guidelines and patient education to collaboratively formulate a plan of care were key elements to assist in the avoidance of antibiotic resistance. 


\section{Framework}

The framework that was used to implement this practice change was the Iowa Model of Evidence-Based Practice. The Iowa Model of Evidence-Based Practice was chosen as the framework because it is known for its strong theoretical model that aids in implementing evidence-based change. The multi-step process of the Iowa Model ensured changes achieve quality outcomes as well as sustainability (White \& Spruce, 2015).

The Iowa model has various steps that helped to guide the process:

1. Identify a problem- antibiotic stewardship was identified as a national, agency, and accrediting body issue.

2. Form a team- the team consisted of the project leader, clinical leader, and medical director.

3. Assemble evidence- a comprehensive literature review was conducted.

4. Critique evidence- a synthesis of evidence was completed, and each article graded.

5. Set forth evidence-based practice recommendations- practice recommendations were identified based on literature review.

6. Identify if findings support practice change- evidence was presented to the clinical leader for proposed practice change.

7. Develop practice change- a evidence-based practice change initiative was developed to address unwarranted antibiotic prescribing. Next pre-intervention antibiotic prescribing rates were evaluated and then the practice change was implemented.

8. Evaluate if practice change occurred-Post-intervention antibiotic prescribing rates were evaluated. 
9. Evaluate structure process and outcomes- Process and outcomes were evaluated and modified. Feedback was then elicited to identify barriers. Necessary adjustments were made to ensure organizational sustainability.

10. Disseminate findings- The results of the change project were then shared with staff and stakeholders.

\section{Change Theory}

Change is a necessary part of growth. Strategies and processes are continually evaluated and modified to maintain optimal growth. To assist with this practice change, Lewin's change theory was deployed. This change theory has been known to help support and sustain high quality outcomes in a multitude of professional settings (Wojciechowski et al., 2016). Lewin's change theory follows three stages: frozen, unfreeze, and refreeze. These three stages include identifying the current practice, pinpointing what can be changed about the current practice, and then implementing change that will result in a new way of performing the practice (Hussain et al., 2016).

The utilization of this change theory was achieved by evaluating the current practice trends when it came to antibiotic prescribing for acute respiratory illnesses, which represented the frozen stage. Next, the practice was unfrozen by sharing with providers the current health concerns surrounding antibiotic resistance related to the management of acute respiratory illnesses. Current evidence-based literature was shared with providers to assist in this process. Providers were informed of current national initiatives that were going to be implemented as well as of similar expectations endorsed by accreditors and payors. Through the above discussions, providers were able to identify the magnitude of this current issue. Providers then had a better understanding of the need to relinquish current treatment practices when managing upper 
respiratory tract infections. In exchange, providers began to utilize nationally recognized evidence-based clinical guidelines and patient education material. The providers' actions represented the refreeze method of this change theory. Through collaborative efforts implemented by the student project leader that were supported by the clinical leader and medical director, all providers were able to identify the current practice problem and recognize the need for the practice change.

\section{Evidence Search Strategy}

To obtain a better understanding of the available evidence of antibiotic stewardship in outpatient settings, a literature review was conducted. The question used to guide the literature review was as follow: In a pediatric outpatient setting for patients ages 6-25 who have no documented uncontrolled comorbidities, presenting with an acute respiratory illness $(\mathrm{P})$, does provider utilization of clinical guidelines, and patient (caregiver) utilization of educational pamphlets, to collectively develop a plan of care (I), compared to providers and patients who do not utilize such strategies $(C)$ result in a reduction in antibiotics prescribed for acute respiratory illnesses $(\mathrm{O})$ in a 6 week timeframe $(\mathrm{T})$ ?

An electronic search was conducted using the University of St. Augustine library portal and Google Scholar. Keyword search was performed using the following: antibiotic stewardship, improved antibiotic prescribing, antibiotic misuse, outpatient, ambulatory, education, outcomes, upper respiratory illnesses, cough, cold, bronchitis. Using a filter of publish dates between 2013-

present, well over 1,000 articles were returned, from the Academic Onefile, CINAHL complete, Info Trac Health Reference Center Academic, General Onefile and eBook index databases. Articles addressing in-patient treatments were excluded from search, as well as microbial specific articles, and articles utilizing laboratory data. Peer reviewed Journals that were 
researched based were used as specified search criteria. Final narrowing was completed by limiting the search to include "antibiotics usage". At this point just under 100 articles were returned. The titles of the articles were reviewed for PICOT relevance. All potential articles identified at this point were further reviewed by exploring the abstracts and identifying articles that are suitable contenders in addressing the affect the practicing of antibiotic stewardship has on the overall reduction in antibiotic prescription ordering within an outpatient setting. Further reduction was made limiting articles to Academic Journal articles that were full text only. The remaining articles were eliminated based on the following non-PICOT relations: pharmacist driven studies, research that utilized diagnostic testing, identifications of specific microorganisms as a focus of study, and finally articles that focused on cost relations. This screening process resulted in 11 articles that directly addressed the focus of the intended PICOT question (see Figure 1- PRISMA for summary of results).

A total of 11 articles were retained and utilized to assist with the proposal development. An evidence level and quality grade were assigned to each article by utilizing the John Hopkins Evidence- Based Practice, Evidence and Quality Guide (see Appendix F). Level I is a study conducted from a fully experimental approach. Level II is a study conducted utilizing a mixed experimental approach, and level III is a study conducted from a nonexperimental approach. Quality ratings are graded A-C. A quality rating of an A identifies studies that show consistent reliable results. A quality rating of a B identifies studies that show consistent results, and a quality rating of a $\mathrm{C}$ identifies studies that have inconsistent results. The evidence level is ranked I-III and the quality scored a B rating (see Table 1).

The articles retained were a grade level 2 with a couple articles being 1 and 3's. The quality of all the articles were a quality level of a B with one single article being a quality level 
A. The design of these articles included clustered randomized, quasi experimental, and linear mixed effect. Out of the 11 articles retained, most articles were quantitative except for one article that was a qualitative study and another article a systematic review.

\section{Themes from the Evidence}

All articles that were reviewed had a similar outcome when it came to the utilization of guidelines and education to reduce antibiotics prescribed for acute respiratory illnesses. In each article the study outcomes had either a modest or profound effect in reducing antibiotics prescribed for acute respiratory illnesses. A synthesis of articles reviewed was conducted to identify similarities in other individual articles that helped to support the PICOT of this paper (see Figure \#2). Emerging themes were identified that consistently had positive outcomes and consisted of the following interventions: clinical guidelines, provider education, regular provider feedback, and patient education.

\section{Clinical Guidelines}

The studies reviewed showed, utilization of clinical guidelines results in a significant reduction in antibiotics prescribed. Clinical guidelines assist providers to formulate treatment plans that are evidence-based and scientifically proven to be the most advantageous approach when treating specific ailments. Providers who have clinical guidelines to reference when treating patients have the benefit of being able to reference the most appropriate treatment plans for their patients. Utilizing clinical guidelines helps to decrease the prescribing of antibiotics when not clinically indicated. The implementation of clinical guidelines resulted in a $95 \%$ compliance rate when it came to the utilization of clinical guidelines to assist in the reduction of antibiotic prescribing (Frisina, 2016). Gifford (2017) noted there are no significant outcome 
differences when giving guidelines in paper form or embedded into the EMR. The key to change is simply providing providers with clinical guidelines.

\section{Provider Education}

According to Holstiege et al. (2015), education is key to achieve adherence to the appropriate utilization of clinical guidelines. Presenting educational material to providers in a multifaceted approach results in improved outcomes (Holstiege et al., 2015). A multifaceted approach helps to encompass the varying learning styles that each individual provider may have. When emphasis is placed on educating the provider through the utilization of guidelines, a vast reduction of antibiotic prescribing is achieved. Providers who have ongoing regular educational sessions, result in higher guideline adherence when treating acute respiratory illnesses (Clegg, 2019). In comparison, when educational sessions are less frequent there is a decrease in guideline adherence resulting in an increase in antibiotics prescribed when not clinically indicated. Educational sessions are important to assist providers with clinical guideline utilization.

\section{Provider Feedback}

The incorporation of provider feedback is an intervention noted to have a positive impact in supporting the reduction of antibiotic prescribing when not indicated for acute respiratory illnesses. Holstiege et al. (2015), emphasized the idea that in addition to the utilization of clinical guidelines accompanied by provider and patient education, providers who have regular feedback regarding their antimicrobial stewardship efforts tend to be more successful at not prescribing antibiotics for acute respiratory illnesses. The key to maintaining adherence to clinical change and utilization of clinical guidelines is to provide providers with feedback on a regular basis (Clegg, 2019). 


\section{Patient Education}

Patients are consumers of their health care. To achieve desired positive health outcomes, patients as well as providers must enter into a collaborative management of care agreement. This collaboration is best achieved when the patient has some sort of background knowledge regarding the treatment approach to the acute ailments. When targeting both providers and patients a vast reduction in antibiotic prescribing can be achieved as both provider and patient are familiar with the appropriate antibiotic prescribing practices surrounding acute respiratory illnesses. Targeting both groups is most impactful at achieving the desired outcome versus targeting either group alone (Wei et al., 2017).

Synthesis of the articles resulted in the identification of several key components that are pivotal in supporting the PICOT discussed in this paper. Clinical guidelines were highlighted as being one of the key major ingredients necessary to achieve the PICOT goal of antibiotic reduction. Clinical guidelines are like the roadmap to guiding this practice change. To accompany the clinical guidelines is the educational component, which requires the education of both the provider as well as patient to achieve the desired outcome. Provider feedback was also identified as being advantageous.

\section{Practice Recommendations}

There were 11 articles that were reviewed seeking evidence to support the PICOT question. The evidence supported providers use of guidelines and patient education to reduce antibiotic prescriptions for diagnosed acute respiratory illnesses. The practice recommendation was to implement the utilization of national clinical guidelines, and supplement this with patient education pamphlets as well as posters, and collaborative patient/provider plan of care development to improve nonessential antibiotic prescribing for the management of acute 
respiratory illnesses. This is compared to providers who did not refer to national clinical guidelines to assist in formulating the treatment plan of care for the management of acute respiratory illness and patients who did not receive any educational material (see Appendix G).

The evidence reported in the literature supports, the combination of clinical providers utilizing clinical guidelines accompanied by patients receiving educational information regarding how to manage acute respiratory illnesses resulted in a reduction in antibiotics being prescribed. Variation was noted in the literature when it came to how significant the reduction of antibiotic prescribing was when evaluated over time. For example, in the study conducted by Gifford et al., (2017), that was conducted over 3.5 years resulted in higher reductions in antibiotics prescribed compared to the study conducted by Meeker et al., (2016), that utilized a 1-year intervention period. In reviewing these two studies it appears that the longer the intervention is in place continued reductions in unnecessary antibiotic prescribing occurs. To sustain this practice change, an annual review mechanism should be implemented after the project to provide feedback to providers on antibiotic prescribing practices.

As payors are increasingly looking for ways to identify quality measures to improve quality of care, regulations, as well as ways to reimburse for the quality of health services rendered (Adirim et al., 2017), organizations and providers must identify, develop, and implement ways to improve quality of care. If providers want to provide the best care for patients and subsequently be reimbursed, the institution needs a strong focus on achieving national quality measures such as HEDIS scores/measurements. HEDIS is used by well over $90 \%$ of health plans to measure performance on important dimensions of care and reimbursement for services (NCQA, 2020). Institutions need to meet the new antimicrobial stewardship requirements as stipulated by the Center for Medicare \& Medicaid Services (CMS) to maximize 
reimbursement, as well as the Joint Commission if they want to maintain their accreditation (Joint Commission, 2019). Sound antibiotic prescribing is one of the national quality measures in the forefront of payor's reimbursement qualifiers at this time, and this PICOT question helps to not only reduce antimicrobial resistance but also assists providers in maximizing reimbursement for services rendered.

\section{Project Setting}

The setting in which the change project took place was within a pediatric outpatient clinic in the Chicagoland area. This pediatric clinic sees approximately 65 patients a day. The pediatric clinic is affiliated with a major medical center and is known for consistently providing quality patient care.

\section{Participant Criteria}

Eligible participants included the 5 providers who practice at the clinic and all patients and caregivers of minors, within the age range of 6-25 and have no history of uncontrolled comorbidities. Patients with uncontrolled comorbidities or who have recently been evaluated and treated in the last 30 days for any ailments were excluded from participation. The patients who fell within the appropriate age category and were otherwise healthy were chosen as participants. Finally, these participants were also required to present to the clinic for guidance and management of symptoms suggestive of an acute upper respiratory illness to be an included participant. All potential participants had to have illness that was otherwise self-limiting, with a low probability for the need of a higher level of care which was confirmed by all exam findings being otherwise normal. All participants had to be able to return home after they were seen and evaluated. 


\section{Mission and Vision}

The pediatric clinic is committed to providing high quality, patient-focused care that is also cost effective. The clinic's mission and vision consist of maintaining a commitment to quality patient care to achieve and maintain superior quality patient outcomes.

\section{Need}

Organizational need was established by evaluating national goals and trends in healthcare and then identifying areas within the pediatric clinic that could benefit from change that was consistent with these national goals and benchmarks. An evaluation of the current antibiotic stewardship initiatives was completed. This clinic had no formal antimicrobial stewardship efforts in place.

In September of 2014, President Barack Obama signed an executive order requiring healthcare facilities to implement concerted efforts to combat antimicrobial resistance (CDC, 2015). The Center for Medicare and Medicaid Services (CMS) required all outpatient facilities of any size (from single to multiple providers) to implement an antibiotic stewardship initiative (CDC, 2015).

The clinical lead and medical director identified the need to meet the CMS requirement of implementing antibiotic stewardship initiatives in efforts to improve antimicrobial stewardship. However, nothing had been formally implemented. Leaders were therefore approached regarding the positive outcomes this change project could achieve. Specifically, the implementation of the evidenced-based changes that were highly likely to assist the pediatric outpatient clinic in meeting national benchmark and goals, as well as maintaining accreditation. After the executive leaders met and agreed, tentative plans were made to assist with the implementation of the proposed changed project. 


\section{Stakeholders}

A single clinical leader was assigned to oversee the project. Major stakeholders consisted of a clinical leader, medical director, the medical providers, clinic staff, patients, and caregivers. After the clinical leader reviewed the change project proposal and discussed it with the medical director, a plan was developed to elicit buy in from the providers.

To assist with the planning phase of this change project a SWOT analysis was completed. The SWOT analysis provided a comprehensive overview of the potential strengths, weaknesses, opportunities as well as threats for implementation of the change project (see Appendix I).

\section{Strengths}

The SWOT analysis identified many helpful strengths. They consisted of clinical leader buy in, the ease of implementation of the change project, little demand for outside resources to accomplish the practice change, and the strong desire by all involved to achieve national benchmarks.

\section{Weaknesses}

Several potential weaknesses were identified. First, a decrease in patients' satisfaction could result when the desired treatment of choice, an antibiotic, is not ordered. There was potential for medical providers to resist using clinical guideline to guide their medical decision making. Lastly, the increased time spent educating each provider and patient could result in a disruption in typical workflow.

\section{Opportunities}

The change project provided an opportunity to consistently emphasize to clinical providers the benefits of clinical guidelines for all associated treatment modalities. An additional bonus was providing the providers educational sessions on how to have confident conversation 
with patients if they encountered pushback about this practice change. Another opportunity was the collaboration between the provider and patient/caregiver to develop the treatment plan of care.

\section{Threats}

One identified threat was the ability to obtain an adequate amount of the "Be Smart" pamphlets that were created and released by the CDC. These pamphlets educate patients about appropriate antibiotic use and were utilized as educational tools for patients during the acute visits. This threat was mitigated by printing pamphlets as allowed by the CDC. Other potential threats were patients/caregiver reading ability and or refusal to review the educational material prior to seeing the provider. Assistance was provided by clinical staff to any patient who reports the inability to read.

\section{Project Overview}

The mission and vision of this change project was to decrease the future risk of antimicrobial resistance through the utilization of clinical guidelines and education for clinical providers as well as patients to reduce inappropriate antibiotic prescribing. The project setting consisted of a pediatric outpatient clinic that regularly manages minor acute self-limiting ailments such as upper respiratory tract infections. 


\section{Mission}

The project mission was consistent with the overall organization's mission. Both the clinic and the project leader wanted to improve health outcomes of the community through the utilization of education and clinical change that is evidenced based.

\section{Goal}

The short-term goals of this project include the provider's consistent use of the guidelines, improved provider's perception of the value of antibiotic stewardship, and a reduction in antibiotics prescribed for acute respiratory illnesses by $10 \%$ in the six-week timeframe post interventions as compared to pre-intervention data. The long-term goal aims to be reduction in antibiotic prescribed for acute respiratory illnesses by at least $15 \%$, compared to preintervention; thereby, contribute to the desired resolution of antibiotic resistance. The targeted goal of a reduction of at least $15 \%$ is consistent with the suggested national outpatient benchmark goal as established by the national action plan for combating antibiotic resistance, for all outpatient facilities (The White House, 2015).

\section{Risks}

One potential risk consisted of providers being placed under extreme pressure by dissatisfied patients. Often patients perceive the need for an antibiotic with any respiratory infection and become upset when the clinical visit does not result in an antibiotic being prescribed. Another potential risk consisted of providers not consistently utilizing the clinical guidelines when formulating the patient's plans of care. If it was found a provider was not utilizing the clinical guidelines as demonstrated by high individual provider prescribing rates, the medical director reinforced guideline adherence through one-on-one audit and feedback. Another risk included patients not receiving an antibiotic when needed or when symptoms 
changed. Patients were strongly encouraged to seek follow up care for any worsening of symptoms so they could be re-evaluated.

\section{Project Plan (Method)}

The creation of the project planning schedule was guided by the IOWA model evidencebased framework. Each step in the project proposal was governed by the steps within the IOWA model to ensure evidence-based practice improvements were achieved. The plans for implementation of this change project are outlined in the table Appendix J.

The project began with this DNP student meeting with the preceptor, who was also the clinical leader. To accomplish the initial step of the IOWA model the project problem was identified, and the topic was shared with the clinical leader and an assessment of the current clinical efforts regarding antibiotic stewardship was ascertained. In the next step of the IOWA model the DNP student, who was also the project leader met with the formed team who consisted of the clinical leader and medical director who reviewed the proposed plan and recommendations. The following steps of the IOWA model of assembling evidence and critiquing the evidence was accomplished by the project leader. The subsequent step of evidencebased practice recommendations was reviewed and shared and adjustments to the project plan were made as suggested by the medical director, and the clinical leader.

A review of the national clinical guidelines for the treatment of upper respiratory tract infections was conducted. The national clinical guidelines were identified, and a clinical order set was created that was used by the clinical providers, when treating upper respiratory tract infections. In accordance with the next step in the IOWA model the clinical guidelines were shared with the clinical lead, and medical director for review. 
Once the project was approved by both the university and the clinic, a survey was administered to evaluate the clinical provider's current attitudes and beliefs regarding antibiotic stewardship. A retrospective review of the average rate of antibiotics prescribed for upper respiratory tract infections for the correlating 6-week intervention timeframe (DecemberJanuary) from the year prior was conducted. This rate served as the pre-intervention comparison rate. Next an antibiotic stewardship presentation was prepared for providers sharing the preintervention rate of prescribing, followed by the introduction of the planned practice change. This project implemented the clinical guideline and an associated order set, evaluated provider knowledge of and satisfaction with the practice change, and improved- the provider/patient decision making process by initiating the use of the CDC endorse antibiotic stewardship information and campaign materials. Small informational sessions were held to review the new antibiotic prescribing clinical guideline order sets to be used, as well as familiarizing providers with the patient CDC antibiotic "Be Smart" pamphlets and posters. Following the informational sessions, Q \& A sessions were scheduled for those providers who wanted additional information/ resource prior to project implementation.

Clinical guideline order sets were made available at all workstations, as well as all educational material 1 week prior to the project go live date. The project went live for a total of 6-weeks and during this phase of the project implementation process the interventions were carried out with close monitoring of its process and outcomes. During this step the project leader closely monitored and ensured all steps of the change project were being carried out. The steps examined included the provider utilization of the clinical guidelines, patients receiving pamphlets, as well as provider and patient collectively developing a treatment plan of care. 
Throughout the 6-week timeframe, the project leader checked in with the clinical leader to discuss any provider questions or concerns. During this time, the project and clinical leader reviewed data obtained to analyze if the project was moving toward the intended directional outcome as well as evaluated the untoward outcomes that were discovered along the way. Data was collected from the EMR weekly, tallying number of patients seen and diagnosed with acute respiratory illness and those prescribed antibiotics along with provider compliance with the guidelines. In addition, the project leader evaluated provider concerns and compared them to appraise the current rate of prescribing. Unforeseen issues and concerns were discussed with the clinical leader and medical director, at the end of week 2 and week 4. This step, which was the evaluate structure and process and outcomes phase of the IOWA model was an important phase as it gave the project and clinical leader the ability to refine planned activities based on the outcomes that were noted to ensure the project was being implemented to the best of its abilities.

The project leader used the EMR to collect interventional antibiotic prescribing rates each week throughout the interventional period. Bi-weekly tallies of current prescribing rates were shared by posting graphs in the staff room. The project implementation phase concluded after the intervention had been in place for 6- weeks.

The final rate of antibiotics prescribed during the implementation phase was calculated. The post-interventional rate of antibiotics prescribed was compared to the pre-interventional rate. Then, the project leader administered the post implementation survey to evaluate if there was a shift in attitudes and beliefs regarding antibiotic stewardship, as well as to identify strengths, weaknesses, and overall opinions of the change project. To achieve the final step in the IOWA model, the final project results were presented in a PowerPoint presentation at a staff meeting 30 days following the completion of the project. 
The required resources for this EBP change project consisted of the utilization of the EMR that was already in place, the implementation of the national clinical guideline to treat acute upper respiratory illnesses, and the CDC "Be Smart" pamphlets and posters. A minimal budget was required to implement this project. Provider familiarization of the guidelines occurred during regularly scheduled staff meetings resulting in no additional cost to pay staff. The primary source of cost was simply the paper and ink to print. There was a small increase in provider time spent educating patients surrounding appropriate antibiotic use; however, this was minimal and did not affect revenue. As CMS and other health plans and payers transforms its payment model from volume-based care models to quality-based payments, the implementation of this project helped to maximize potential payor reimbursement as HEDIS quality measures for appropriate prescribing were achieved. Achieving these evidence-based practice changes that improved patient focused outcomes far exceeded any potential minor increase in cost (Kliethermes, 2019).

\section{Leadership Role}

As the leader of this planned change project, this DNP student displayed the following qualities: good communication and organizational skills, the ability to multi-task, as well as flexibility when there was needed changes. The project leader oversaw all aspects of this change project from the planning phase, through the start and finish. Effective communication and collaboration with the key stakeholders were mandatory for success. Time was spent familiarizing staff with the clinical guidelines and its utilization, as well as familiarizing staff about the patient's pamphlet. A considerable amount of time was spent communicating with the clinical leader who was the access point into the pediatric clinic. The clinical leader was the main point of contact within the clinic, and facilitated contact with medical directors, medical 
providers, and staff. The project leader was responsible for implementing a timeline for activities to be completed, as well as overseeing tasks were being completed. Feedback from the team was regularly elicited to gain insight regarding how the project was progressing. The project leader was receptive to the information shared by other stakeholders and responsive to improve and/or rectify any issues that arose. These leadership qualities were crucial, to successfully carryout this change project.

\section{Results}

To evaluate the outcome of this planned change project, multiple steps were initiated. Participants were selected based on diagnosis, age, and absence of co-morbidities. All participants selected had been seen, evaluated, and diagnosed with acute respiratory illness. Participants had to be otherwise healthy with no uncontrolled comorbidities to be selected for participation. All patients and caregivers seen within the pediatric care setting received the educational intervention; however, only the patients meeting the above criteria were included as participants to be evaluated for the practice change.

\section{Provider Survey}

The provider survey was administered prior to the start of the intervention and at the conclusion of the intervention. Provider post-intervention surveys were compared to preintervention surveys seeking to identify any change in knowledge attitude or beliefs, about antibiotic stewardship. A copy of the provider survey can be found in Appendix E, accompanied by a modification permitted statement. 


\section{EMR Review}

The EMR was utilized to review all patient visits, however, only the patients that met the above criteria were included as participants of the change project. Once participants who met the criteria were identified, a quantitative analysis was conducted to identify the number of patients who were prescribed antibiotics after the educational interventions were implemented. The number of antibiotics prescribed to patients was assessed and collected at weeks 2,4 , and 6 . The number of participants diagnosed with an acute respiratory illness and the number of participants prescribed an antibiotic was the only outcome data collected from the EMR. Prior to the start of the practice change, retrospective data was collected to serve as the comparison group. A baseline retrospective evaluation was collected from the EMR. This retrospective data evaluation was conducted by identifying patients who were seen in the corresponding six-week timeframe (December-January) the year prior to intervention who also met the above criteria, and then calculating the rate of antibiotic prescribed prior to the initiation of the intervention. This information was earmarked as being the pre-intervention comparison group.

\section{Data Collection}

The antibiotic prescription data was collected from the EMR. The CDC (2019) recommends the use of electronical medical records as a means for collecting data to analyze prescribing trends. The student project leader who initiated the practice change collected the data from the EMR with the support and guidance of the clinical leader. Collection of data was performed for each individual provider. This allowed tracking of each individual provider's prescribing rates and guideline compliance. Once data was collected for each provider, it was tallied together to reflect the total prescribing habits of all the clinic providers. Any patient chart, that had missing data or did not achieve the three selection criterions were excluded as 
qualifiable participants for the practice change. The data collected was stored and collected only after the patient was deidentified to ensure privacy of the health information. This was fully achieved by not using patients' names and simply keeping a running tally of the quantity of patients seen as well as those who were prescribed antibiotics. Anonymity of provider names when evaluating individual prescribing rates was also maintained when collecting data by assigning each provider to a number 1-5. This information was then entered into an excel document and stored in the student project leader's laptop. This laptop was only accessible by coded entry access. After the collected data had been analyzed, the post intervention rate of prescribing had to be less than the rate of prescribing in the pre-intervention group in ordered for the project to be considered clinically significant. The provider pre- and post-intervention surveys were compared to evaluate for any change in provider attitudes and beliefs regarding antibiotic stewardship. Individual provider prescribing rates was not compared given the use of the CDC guidelines and materials were new to the clinic but will assist in providing information to help sustain the change in practice.

\section{Interventional Assessments}

Following project initiation, an assessment of the interventional changes was conducted every 2 weeks of the 6-week interventional timeframe. Please see Appendix $\mathbf{J}$ for list of scheduled activities. To consider the interventional outcomes as being clinically meaningful improvements, the interventional rate of antibiotics prescribed had to be less than the retrospective analysis number of the comparison group. The quantitative data was gathered and then the total number of antibiotics prescribed were calculated, for the pre and post intervention periods. During the preimplementation period of the project there was a total of three hundred ninety-eight (398) antibiotics prescribed, as compared to the post implementation were there was a total of ninety- 
three (93) antibiotics prescribed. Therefore, the utilization of clinical guidelines and education for clinical providers as well as patients to reduce inappropriate antibiotic prescribing was effective when treating acute respiratory illnesses based on these results (See Figure 2).

A paired t-test was used to compare pre- and post-antibiotics prescribed. As seen in Table 4, there was a statistically significant difference between the score of pre $(M=13.27, S D=7.90)$ and post $(\mathrm{M}=3.10, \mathrm{SD}=1.86)$ results. The $\mathrm{t}-\mathrm{value}$ was 8.722 , which was significant at alpha $=0.05$, resulting in statistically significant differences between the results of pre-and post-antibiotics prescribed. The practice changes implemented, successfully decreased antibiotic prescribing for acute respiratory illness at this clinic.

The data produced from the provider pre- and post-implementation survey was ordinal. Higher scores are associated with more favorable opinions. Post implementation provider surveys showed a more favorable opinion when it came to the value of antibiotic stewardship. Individual provider prescribing rates were reported as a percentage, with a goal of $<10 \%$. Higher individual prescribing rates were associated with nonadherence to clinical guidelines.

This EBP change project was reviewed and approved by the Evidence Based Practice review committee (EPRC) through the University of St. Augustine as well as the pediatric clinic's medical director prior to initiation. Human rights were protected throughout the practice change project and the data collected was de-identified. The change itself presented no potential harm to the patients.

\section{Impact}

The findings of this evidence-based practice change seeking to address the unwarranted antibiotic prescribing for acute respiratory illnesses in a pediatric setting, substantiated that the utilization of clinical practice guidelines and patient education can significantly reduce the 
number of inappropriate antibiotics being prescribed. Initially, providers in the pediatric setting were prescribing antibiotics at a rate of $82 \%$ when managing acute respiratory illness. After implementation of the 6-week evidence-based practice change, this rate decreased to $42 \%$. These findings are consistent with those of past literature that reported the utilization of clinical guidelines, patient education, and collaborative formation of the plan of care, resulted in an overall reduction in antibiotics prescribed when managing acute respiratory illnesses.

To accomplish this clinical practice change, the providers in this pediatric clinical setting made a concerted effort to achieve best prescribing practice by utilizing national clinical guidelines for the management of acute respiratory illnesses. This student project leader believes the success of this project was in large due to the staunch support of the medical director who fostered encouragement and buy in from the providers. The medical director and provider support, coupled with patient education, manifested a new prescribing culture within this pediatric clinic. These improved prescribing practices enhanced outcomes for the patients, fulfilled federal and regulatory requirements, and improved reimbursement for services. Most importantly, these newly adopted practice changes will help to win the global battle to combat antimicrobial resistance.

To support the continued success and sustainability of this practice change the clinic will incorporate antibiotic stewardship reviews, routine chart audits, provider feedback, and communications. These practices will highlight the clinic's overall commitment to antibiotic stewardship. Further, they will continue to gather data on individual provider prescribing rates, to evaluate national clinical guideline adherence.

This student project leader believes one of the greatest limitations experienced during this change project was the impact COVID-19 placed on the vast reduction in quantity of patients 
seen during the implementation phase as compared to the pre-implementation phase. The provider survey results indicated patients and caregivers commonly placed undue pressure on providers to prescribe antibiotics for viral ailments.

However, the lower patient volume meant providers could spend more time focusing on proper clinical guideline-based management, care, and education for each patient. It could be assumed that, without this lower patient volume, implementation of such clinical practice change could have resulted in increased stress for providers. With less time for education, the providers might have steered away from clinical guidelines and given in to patient demand. However, the individual provider prescribing monitoring and feedback suggested the actual final prescribing rate would have been only slightly higher if the pandemic had not been a factor.

The lower patient volume was advantageous in the sense that it allowed providers the opportunity to become familiar with this practice change, which, will help solidify the changes into a routine when moving forward. When patient volume returns closer to normal levels, providers will already have a strong grasp on this practice change, which will support its sustainability.

\section{Plans for Dissemination}

The results of the change project were shared with staff and stakeholders every two weeks throughout the project by posting graphs on the unit. The final project results were first shared with the clinical leader and medical director to discuss sustainability measures such as standard operating policy, and annual reviews on prescribing rates and individual provider prescribing performance. Next, project results were shared at a staff meeting 2 weeks after completion of this project. All providers and staff in the pediatric clinic were invited to attend the presentation. 
The student project leader will also share the results of the change project via poster and PowerPoint presentations at the American Academy of Pediatrics virtual conference. Since antimicrobial resistance is a global problem, sharing the findings of this project can help to improve antimicrobial stewardship policies in the pediatric clinical settings worldwide. Prior to any professional submissions, abstracts, presentations, and manuscripts will be subjected to a minimum of 3 separate peer reviews.

\section{Conclusion}

The CDC (2013) describes antibiotics as powerful drugs that have transformed health care and have saved millions of lives. However, when not prescribed judiciously, antibiotics can be a very serious threat to mankind. This change project addressed the need for improved antibiotic stewardship. Evidence to support a change project was collected and evaluated to provide practice recommendations and strategies to decrease antibiotic prescriptions in the management of acute respiratory conditions in a pediatric outpatient clinic. Given the widely recognized growing threat of antimicrobial resistance and the available evidence supporting the benefits of outpatient antimicrobial stewardship programs, there was a compelling argument for the implementation of such practice changes (Drekonja, 2015). These programs have achieved significant reductions in the amount of non-medically indicated antibiotic prescriptive practices. The reductions have proven to improve patient outcomes, decrease antibiotic resistance, and diminish wasted healthcare dollars (CDC, 2019). Using antibiotics appropriately is everyone's responsibility, and providers have the greatest power to control unnecessary prescriptions (Harris et al., 2016). This antimicrobial stewardship program, which was implemented in just a few weeks, represented a step in the right direction to address a serious U.S. health problem. 


\section{References}

Adirim, T., Meade, K., \& Mistry, K. (2017). A new era in quality measurement: The development and application of quality measures. American Academy of Pediatrics, 139(1). https://doi.org/10.1542/peds.2016-3442

Alligood, M. R. (2014). Nursing theorists and their work (8th ed.). St. Louis, MO:Elsevier

Barlam, T.F., Cosgroave, S.E., Abbo, L.M., MacDougall, C., Schuetz, A.N., Septimus, E.J., Srinivasan, A., Dellitt, T.H., Flack-Ytter, Y.T., Fishman, N.O., Hamilton, C.W., Jenkins, T.C., Lipsett, P.A., Malani, P.N., May, L.S., Moran, G.J., Neuhauser, M.M., Newland, J.G., Ohl, C.A.,...Trivedi, K.K. (2016). Implementing an antibiotic stewardship program: Guidelines by the Infectious Diseases Society of America and the Society for Healthcare Epidemiology of America. Clinical Infectious Disease, 62(10), e51-77.

Barlam, T.F., Soria-Saucedo, R., Cabral, H.J. \& Kazis, L.E. (2015). Unnecessary antibiotics for acute respiratory tract infections: association with care setting and patient demographics. https://doi.org/10.1093/ofid/ofw045

Biezen, R., Brijnath, B., Grando, D., \& Mazza, D. (2017). Management of respiratory tract infections in young children- A qualitative study of primary care providers' perspectives. Nature Partner Journal, 27(15). 1-7.

Center for Disease Control. (n.d.). Antibiotic/ antimicrobial resistance. Retrieved March 2020, from https://www.cdc.gov/drugresistance/index.html

Center for Disease Control. (2013). Antibiotic resistance threats in the United States. http://www.cdc.gov/drugresistance/threat-report-2013/index.html 
Center for Disease Control. (2019). Measuring outpatient antibiotic prescribing.

https://www.cdc.gov/antibiotic-use/community/programs-measurement/measuringantibioticprescribing.html

Center for Disease Control. (2018). MITIGATE antimicrobial stewardship toolkit. https://qioprogram.org/sites/default/files/editors/141/MITIGATE_TOOLKIT_final_appro ved\%281\%29_508.pdf

Center for Disease Control. (2015). National action plan for combating antibiotic-resistant bacteria.

https://www.cdc.gov/drugresistance/pdf/national_action_plan_for_combating_antiboticresistant_bacteria.pdf

Clegg, H.W., Bean, R. A., Ezzo, S. J., Hoth, A. N., Sheedy, D. J., \& Anderson, W.E., (2019). Impact of education and peer comparison on antibiotic prescribing for pediatric respiratory tract infections. Pediatric Quality and Safety, 4(4).

Drekonja, D., Filice, G., Greer, N., Olson, A., MacDonald, R., Rutks, I., \& Wilt, T., (2015). Antimicrobial stewardship in outpatient settings: a systematic review. Infection Control Hospital Epidemiology, 36(2), 142-152.

https://doi.org/10.1017/ice.2014.41

Feiring, E., \& Walter, B. (2017). Antimicrobial stewardship: a qualitative study of the development of national guidelines for antibiotic use in hospitals. BioMed Central Health Services Research, 17(1), 747). https://doi.org/10.1186/s12913-017-2683-4

Frisina, P., Pletcher, J., Munene, E., \& Kolligian, J., (2016). Antibiotic stewardship for acute bronchitis: a quality improvement study in university healthcare. BMJ 25(12). 
Gifford, J., Vaeth, E., Richards, K., Siddiqui, T., Gill, C., Eilson, L., \& DeLisle, S., (2017). Decision support during electronic prescription to stem antibiotic overuse for acute respiratory infections: a long-term, quasi-experimental study. BMC Infectious Diseases. 17(528), 1-8. https://doi.org/10.1186/s12879-017-2602-7

Gulliford, M.C., Moore, M.V., Little, P., Hay, A.D., Fox, R., Prevost, T., Juszczyk, D., Charlton, J., \& Asworth, M. (2016). Safety of reduced antibiotic prescribing for self-limiting respiratory tract infections in primary care: cohort study using electronic health records. $B M J, 354(\mathrm{i} 3410)$.

Harris, A.M., Hicks, L.A., Qaseem, A. (2016). Appropriate antibiotic use for acute respiratory tract infections in adults: advice for high-value care from the American College of Physicians and the Centers for Disease Control and Prevention. American College of Physicians, 164(6), 425-435.

Holstiege, J., Mathes, T., \& Pieper, D. (2015). Effects of computer-aided clinical decision support systems in improving antibiotic prescribing by primary care providers: a systematic review. Journal of American Medical Information Association, 22, 236-242.

Hopkins, J. (2017). Evidence level and quality guide.

Retrieved from https://www.hopkinsmedicine.org/evidence-based-practice

Hussain, S., Lei, S., Akram, T., Haider, M., Hussain, S., \& Ali, M. (2016). Kurt Lewin's change model: A critical review of the role of leadership and employee involvement in organizational change. Journal of Innovation \& Knowledge, 3(2018), 123-127.

Institute for Healthcare Improvement (2020). Science of improvement testing change. http://www.ihi.org/resources/Pages/HowtoImprove/ScienceofImprovementTestingChanges.aspx 
Iowa Model of Evidence-Based Practice: Revisions and Validations. (2017). World Views on Evidence Based Nursing, 14(3), 175-182.

Joint Commission. (2019, June). Antimicrobial stewardship in ambulatory health care. https://www.jointcommission.org/standards/r3-report/r3-report-issue-23-antimicrobialstewardship-in-ambulatory-health-care/

Kliethermes, M.A., (2019). Value -based payment: Preparing for changes in payment for services. Pharmacy Today, 25(9),44-53. https://www.pharmacytoday.org/article/S1042-0991(19)30939-9/pdf333

Meeker, D., Linder, J.A., Fox, C.R., Friedberg, M.W., Persell, S.D., Goldstein, N.J., Knight, T.K., Hay, J.W., \& Doctor, J.N., (2016). Effects of behavioral interventions on inappropriate antibiotic prescribing among primary care practices a randomized clinical trial. JAMA, 315(6), 562-570.

National Committee for Quality Assurance. (2020). Avoidance of antibiotic treatment in adults with acute bronchitis. https://www.ncqa.org/hedis/measures/avoidance-of-antibiotic-treatment-in-adults-withacute-bronchitis/

O’Sullivan, J.W., Harvey, R.T., Glasziou, P.P., \& McCullough, A., (2016). Written information for patients (or parents of child patients) to reduce the use of antibiotics for acute upper respiratory tract infections in primary care. Cochrane Library, 11. https://doi.org/10.1002/14651858

Ouldali, N., Bellettre, X., Milcent, K., Guedj, R., de Pontual, L., Cojocaru, B., Soussan-Banini, V., Craiu, I., Skurni, D., Gajdos, V., Cheron, G., Cohen, R., Alberti, C., \& Angoulvant, F. (2017). Impact of implementing national guidelines on antibiotic prescriptions for 
acute respiratory tract infections in pediatric emergency departments: An interrupted time series analysis. Clinical Infectious Disease, 65(9), 1469-1476.

Petiprin, A., (2016). Lewin's change theory. Nursing Theory. Retrieved from: https://www.nursing-theory.org/theories-and-models/Lewin-Change-Theory.php

Sanchez, G., Fleming-Dutra, K., Roberts, R., \& Hicks, L. (2016). Core elements of outpatient antibiotic stewardship. MMWR 65(6), 1-13.

Srinivasan, A. (2017). Antibiotic stewardship: why we must, how we can. Cleveland Clinical Journal of Medicine, 84(9), 673-679.

The Journal of Pediatrics. (2021). About the journal. https://www.jpeds.com/content/aims

The White House. (2015). National action plan for combating antibiotic- resistant bacteria. https://obamawhitehouse.archives.gov/sites/default/files/docs/national_action_plan_for_c ombating_antibotic-resistant_bacteria.pdf

Wei, X., Zhang, Z., Walley, J., Hicks, J., Zeng, J., Deng, S., Zhou, Y., Yin, J., Newell, J., Sun, Q., Zou, G., Guo, Y., Upsjur, R. E., \& Lin, M. (2017). Effects of training and educational interventions for physicians and caregivers on antibiotic prescribing for upper respiratory tract infections in children at primary care facilities in rural China a cluster- randomized controlled trial. Lancet Globe Health, 5(12), e1258-e1267. https://doi.org/10.1016/S2214-109X(17)30383-2

Wei, X., Zhang, Z., Walley, J., Hicks, J., Zeng, J., Walley, J.D., King, R., \& Newell, J. N. (2019). Long-term outcomes of an educational intervention to reduce antibiotic 
prescribing for childhood upper respiratory tract infections in rural China: Follow-up of a cluster-randomized controlled trial. PLos Medicine, 16(2).

White, S., Spruce, L. (2015). Perioperative nursing leaders implement clinical practice guidelines using the IOWA Model of Evidence-Based Practice. AORN, 102(1), 50-59. https://doi.org/10.1016/j.aorn.2015.04.001

Wojciechowski, E., Pearsall, T., Murphy, P., \& French, E. (2016). A case review: Integrating Lewin's theory with Lean's system approach for change. The Online Journal of Issues in Nursing, 21(2), 4. https://doi.org/10.3912/OJIN.Vol21No02Man04

Yadav, K., Meeker, D., Mistry, R.D., Doctor J., Fleming-Dutra, K. E., Fleischman, R. J., Gaona, S.D., Stahmer, A., \& May, L. (2019). A multifaceted intervention improves prescribing for acute respiratory infection for adults and children in emergency department and urgent care settings. Academic Emergency Medicine, 26(7), 719-730. 
Table 1:

Article Review Level \& Rating

\begin{tabular}{|c|c|}
\hline Evidence Level & \# Articles Meeting This Criteria \\
\hline I & 5 \\
\hline II & \multicolumn{1}{|c|}{1} \\
\hline III & - \\
\hline IV & - \\
\hline V & \# Articles Meeting This Criteria \\
\hline Quality Grade & 2 \\
\hline A (high quality) & 10 \\
\hline B (good quality) & \\
\hline C (low quality) & - \\
\hline
\end{tabular}


Table 2:

Budget

\begin{tabular}{|c|r|l|r|}
\hline EXPENSES & & REVENUE & \\
\hline Direct & $\$ 0$ & Billing & $\$ 0$ \\
\hline Salary and benefits & $\$ 0$ & Grants & $\$ 0$ \\
\hline Supplies: paper \& ink & $\$ 400$ & Institutional budget support & $\$ 0$ \\
\hline Services & $\$ 0$ & & \\
\hline Statistician & $\$ 500$ & & \\
\hline Indirect & & & \\
\hline Overhead & $\$ 0$ & & \\
\hline Total Expenses & $\$ 0$ & & \\
\hline Net Balance & $\$ 900$ & Total Revenue & \\
\hline
\end{tabular}


Table 3:

Synthesis

Setting Study Timing Outcome Effect

\begin{tabular}{|c|c|c|c|c|c|c|}
\hline Article Names & ED/UC & Office & $<24 \mathrm{mos}$ & $>24 \mathrm{mos}$ & Modest & Profound \\
\hline $\begin{array}{l}\text { Barlam, T.F., } \\
\text { Cosgroave, S.E., } \\
\text { Abbo, L.M., } \\
\text { MacDougall, C., } \\
\text { Schuetz, A.N., \& } \\
\text { Septimus, } \\
\text { E.J.,...Trivedi, K.K. } \\
\text { (2016). Implementing } \\
\text { an antibiotic } \\
\text { stewardship program: } \\
\text { guidelines bythe } \\
\text { infectious diseases' } \\
\text { society of America and } \\
\text { the society for } \\
\text { healthcare } \\
\text { epidemiology of } \\
\text { America. Clinical } \\
\text { Infectious Disease, 62, } \\
\text { e51. }\end{array}$ & $X$ & $\mathrm{X}$ & & $\mathrm{X}$ & & $\mathrm{X}$ \\
\hline $\begin{array}{l}\text { Biezen, R., Brijnath, } \\
\text { B., Grando, D., \& } \\
\text { Mazza, D. (2017). } \\
\text { Management of } \\
\text { respiratory tract } \\
\text { infections in young } \\
\text { children- A qualitative } \\
\text { study of primary care } \\
\text { providers' } \\
\text { perspectives. Nature } \\
\text { Partner Journal, } \\
\text { 27(15). 1-7. }\end{array}$ & & $\mathrm{X}$ & $\mathrm{X}$ & & $\mathrm{X}$ & \\
\hline $\begin{array}{l}\text { Clegg, H.W., Bean, R. } \\
\text { A., Ezzo, S. J., Hoth, } \\
\text { A. N., Sheedy, D. J., \& }\end{array}$ & & $\mathrm{X}$ & $\mathrm{X}$ & & & $\mathrm{X}$ \\
\hline
\end{tabular}




\begin{tabular}{|c|c|c|c|c|c|}
\hline $\begin{array}{l}\text { Anderson, W.E., } \\
\text { (2019). Impact of } \\
\text { education and peer } \\
\text { comparison on } \\
\text { antibiotic prescribing } \\
\text { for pediatric } \\
\text { respiratory tract } \\
\text { infections. Pediatric } \\
\text { Quality and Safety, } \\
\text { 4(4). }\end{array}$ & & & & & \\
\hline $\begin{array}{l}\text { Feiring, E., \& Walter, } \\
\text { B. (2017). } \\
\text { Antimicrobial } \\
\text { stewardship: a } \\
\text { qualitative study of the } \\
\text { development of } \\
\text { national guidelines for } \\
\text { antibiotic use in } \\
\text { hospitals. BioMed } \\
\text { Central Health } \\
\text { Services Research } \\
\text { 17,(747). Doi: } \\
\text { 10.1186/s12913-017- } \\
\text { 2683-4 }\end{array}$ & $X$ & $X$ & & $\mathrm{X}$ & \\
\hline $\begin{array}{l}\text { Frisina, P., Pletcher, J., } \\
\text { Munene, E., \& } \\
\text { Kolligian, J., (2016). } \\
\text { Antibiotic stewardship } \\
\text { for acute bronchitis: a } \\
\text { quality improvement } \\
\text { study in university } \\
\text { healthcare. BMJ } \\
25(12) .\end{array}$ & $\mathrm{X}$ & $\mathrm{X}$ & & & $\mathrm{X}$ \\
\hline $\begin{array}{l}\text { Gifford, J., Vaeth, E., } \\
\text { Richards, K., Siddiqui, } \\
\text { T., Gill, C., Eilson, L., } \\
\text { \& DeLisle, S., (2017). } \\
\text { Decision support } \\
\text { during electronic } \\
\text { prescription to stem }\end{array}$ & $\mathrm{X}$ & & $\mathrm{X}$ & & $\mathrm{X}$ \\
\hline
\end{tabular}




\begin{tabular}{|c|c|c|c|c|c|}
\hline $\begin{array}{l}\text { antibiotic overuse for } \\
\text { acute respiratory } \\
\text { infections: a long- } \\
\text { term, quasi- } \\
\text { experimental study. } \\
\text { BMC Infectious } \\
\text { Diseases. } 17(528), 1-8 . \\
\text { Doi:10.1186/s12879- } \\
\quad 017-2602-7 \\
\end{array}$ & & & & & \\
\hline $\begin{array}{l}\text { Gulliford, M.C., } \\
\text { Moore, M.V., Little, } \\
\text { P., Hay, A.D., Fox, R., } \\
\text { Prevost, T., .. Asworth, } \\
\text { M. (2016).Safety of } \\
\text { reduced antibiotic } \\
\text { prescribing for self- } \\
\text { limiting respiratory } \\
\text { tract infections in } \\
\text { primary care: cohort } \\
\text { study using electronic } \\
\text { health records. BMJ, } \\
\text { 354(i3410). }\end{array}$ & $\mathrm{X}$ & & $X$ & & $X$ \\
\hline $\begin{array}{l}\text { O'Sullivan, J.W., } \\
\text { Harvey, R.T., } \\
\text { Glasziou, P.P., \& } \\
\text { McCullough, A., } \\
\text { (2016). Written } \\
\text { information for } \\
\text { patients (or parents of } \\
\text { child patients) to } \\
\text { reduce the use of } \\
\text { antibiotics for acute } \\
\text { upper respiratory } \\
\text { tract infections in } \\
\text { primary care. } \\
\text { Cochrane Library, } 11 . \\
\text { Doi:10.1002/14651858 }\end{array}$ & $X$ & $\mathrm{X}$ & & $X$ & \\
\hline $\begin{array}{l}\text { Wei, X., Zhang, Z., } \\
\text { Walley, J., Hicks, J., } \\
\text { Zeng, J., Deng, S. } \\
\text {....., \& Lin, M. } \\
\text { (2017). Effects of } \\
\text { training and } \\
\text { educational }\end{array}$ & $X$ & $\mathrm{X}$ & & & $X$ \\
\hline
\end{tabular}




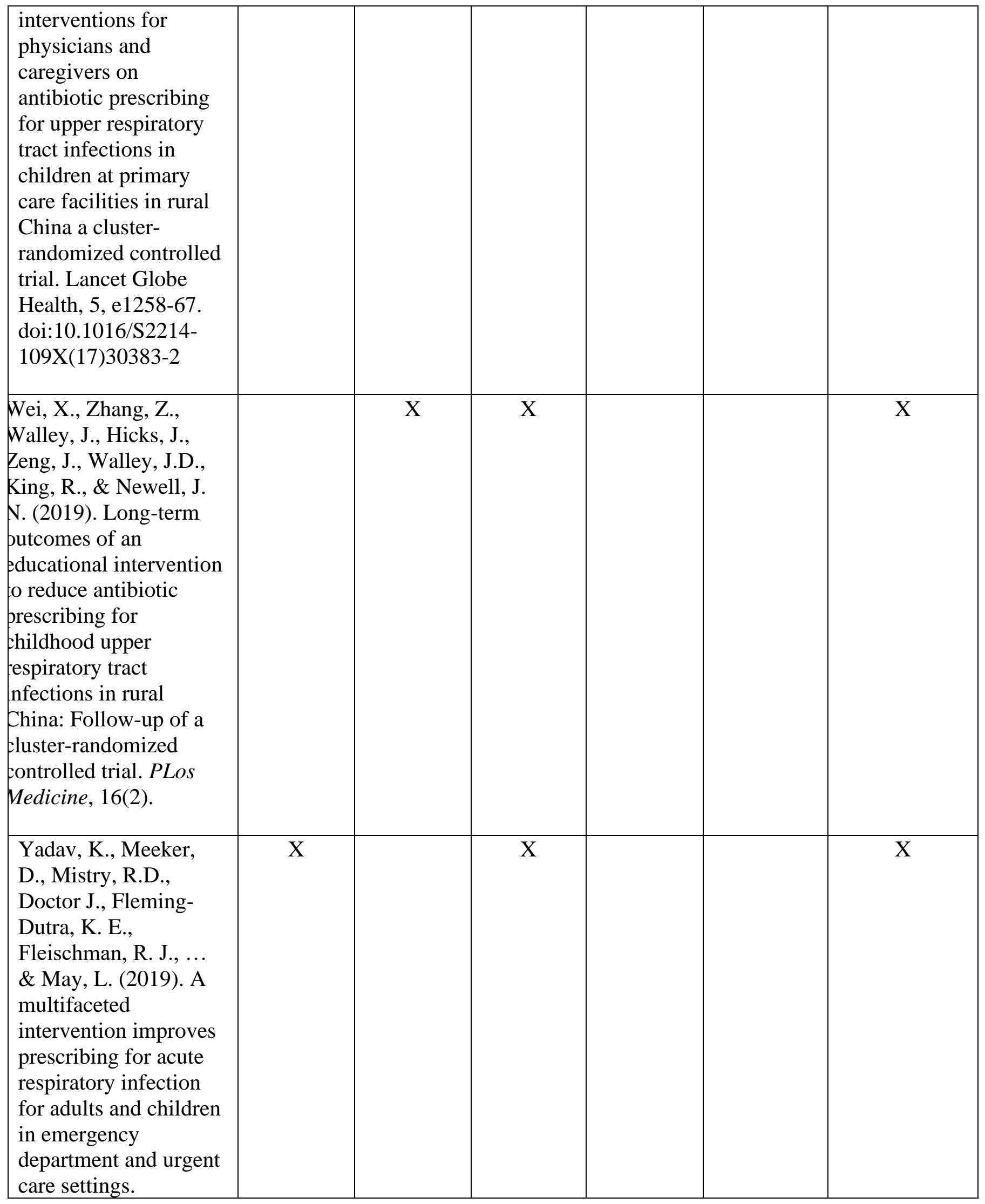


Academic Emergency

Medicine, 26(7), 719-

730. 
Table 4:

Pre and Post Antibiotic Prescribed Paired Sample Statistics.

\begin{tabular}{ccccccc}
\hline Variables & $N$ & Mean & $S D$ & $D f$ & t-value & p-value \\
\hline $\begin{array}{c}\text { Pre-Antibiotic } \\
\text { Prescribed }\end{array}$ & 398 & 13.27 & 7.90 & & & \\
$\begin{array}{c}\text { Post- Antibiotic } \\
\text { Prescribed }\end{array}$ & 93 & 3.10 & 1.86 & & & 0.05 \\
\hline
\end{tabular}

Significant at the 0.05 level (2-tailed) 
Figure 1

PRISMA

\section{PRISMA DIAGRAM}

\section{Records identified through database}

Additional records identified through

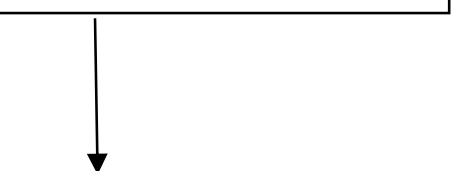

Records after duplicates removed $(n=971)$

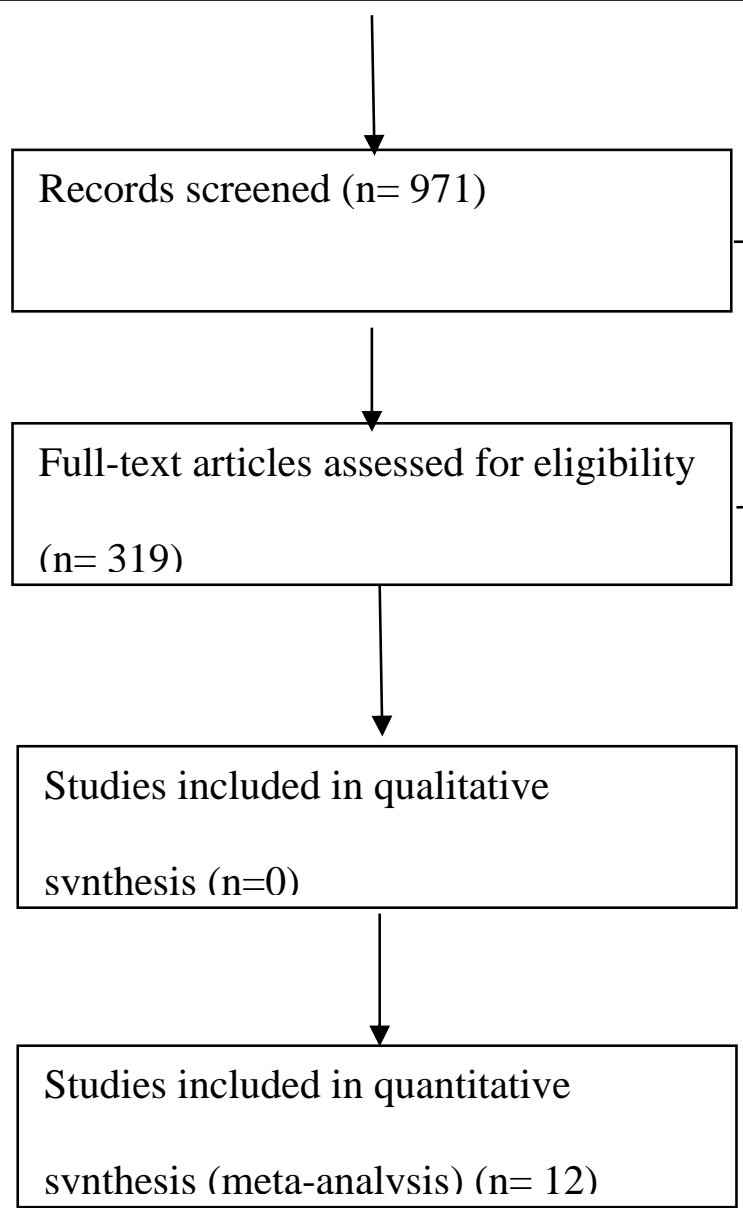

Records excluded $(n=652)$

Studies included in quantitative

svnthesis (meta-analvsis) $(\mathrm{n}=12)$ 
Figure 2

Antibiotics Prescribed

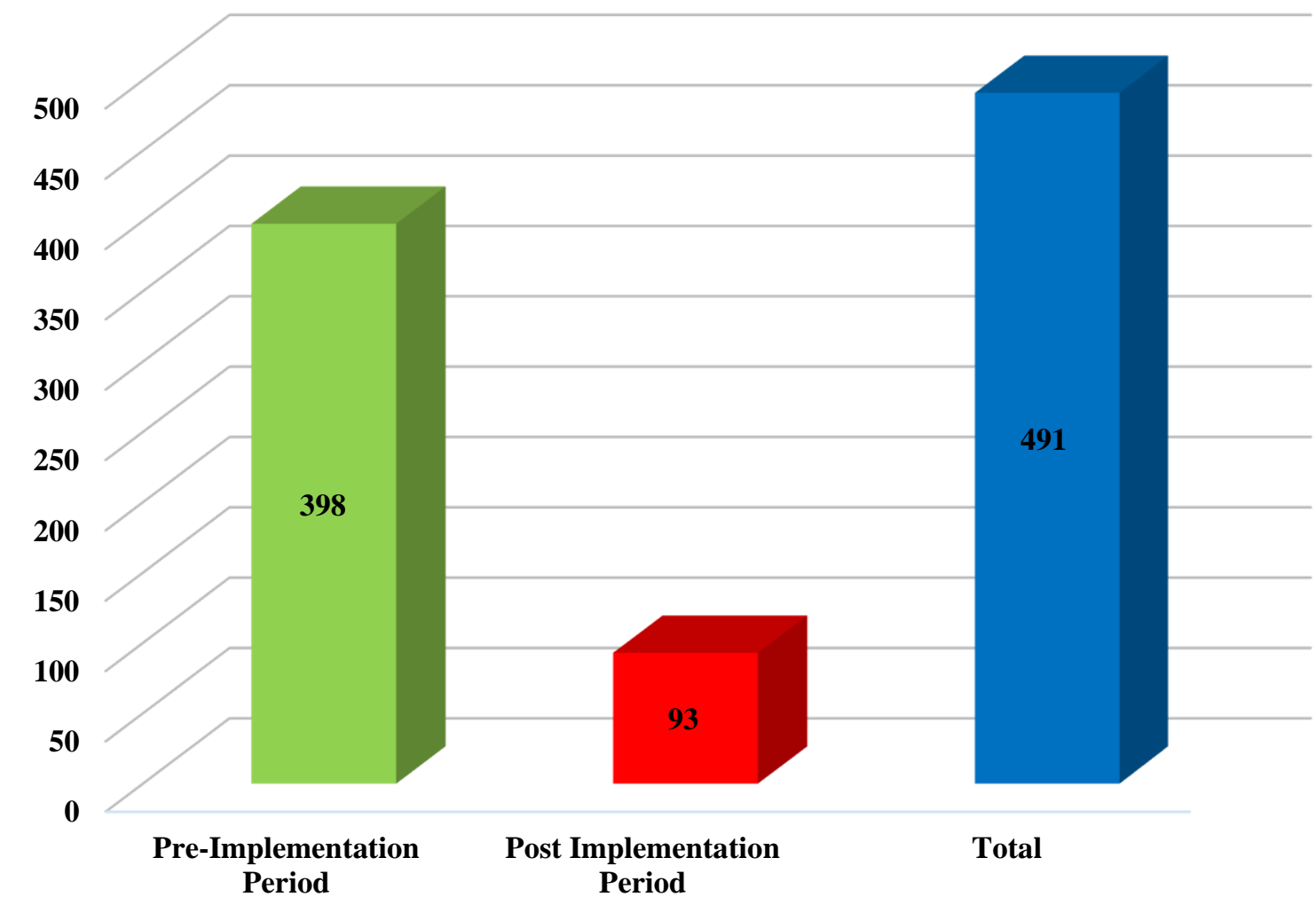

Figure 2. Designates frequency distribution by Total number of antibiotics prescribed. 


\section{Appendix A}

\section{CDC Pediatric Outpatient Treatment Recommendations}

\begin{tabular}{|c|c|c|c|}
\hline $\begin{array}{l}\text { CDC Pediatric } \\
\text { Outpatient } \\
\text { Treatment } \\
\text { Recommendations }\end{array}$ & & & \\
\hline Condition & Epidemiology & Diagnosis & Management \\
\hline Acute sinusitis $\frac{1,2}{2}$ & $\begin{array}{l}\text { - Sinusitis may be } \\
\text { caused by viruses } \\
\text { or bacteria, and } \\
\text { antibiotics are not } \\
\text { guaranteed to } \\
\text { help even if the } \\
\text { causative agent is } \\
\text { bacterial. }\end{array}$ & $\begin{array}{l}\text { Halitosis, fatigue, headache, decreased } \\
\text { appetite, but most physical exam findings } \\
\text { are non-specific and do not distinguish } \\
\text { bacterial from viral causes. } \\
\text { A bacterial diagnosis may be established } \\
\text { based on the presence of one of the } \\
\text { following criteria: } \\
\text { - Persistent symptoms without } \\
\text { improvement: nasal discharge or } \\
\text { daytime cough }>10 \text { days. } \\
\text { Worsening symptoms: worsening or } \\
\text { new onset fever, daytime cough, or } \\
\text { nasal discharge after initial } \\
\text { improvement of a viral URI. } \\
\text { Severe symptoms: fever } \geq 39^{\circ} \mathrm{C} \text {, } \\
\text { purulent nasal discharge for at least } 3 \\
\text { consecutive days. } \\
\text { Imaging tests are no longer recommended } \\
\text { for uncomplicated cases. }\end{array}$ & $\begin{array}{l}\text { If a bacterial infection is established: } \\
\text { - Watchful waiting for up to } 3 \text { days may } \\
\text { be offered for children with acute } \\
\text { bacterial sinusitis with persistent } \\
\text { symptoms. Antibiotic therapy should be } \\
\text { prescribed for children with acute } \\
\text { bacterial sinusitis with severe or } \\
\text { worsening disease. } \\
\text { - Amoxicillin or amoxicillin/clavulanate } \\
\text { remain first-line therapy. } \\
\text { Recommendations for treatment of } \\
\text { children with a history of type I } \\
\text { hypersensitivity to penicillin vary. } \text {. }^{1,2} \\
\text { In children who are vomiting or who } \\
\text { cannot tolerate oral medication, a single } \\
\text { dose of ceftriaxone can be used and } \\
\text { then can be switched to oral antibiotics } \\
\text { if improving. }{ }^{1} \\
\text { For further recommendations on } \\
\text { alternative antibiotic regimens, consult } \\
\text { the American Academy of Pediatrics }{ }^{1} \text { or }\end{array}$ \\
\hline
\end{tabular}




\begin{tabular}{|c|c|c|c|}
\hline & & & $\begin{array}{l}\text { the Infectious Diseases Society of } \\
\text { America }^{2} \text { guidelines. }\end{array}$ \\
\hline $\begin{array}{l}\text { Acute otitis media } \\
(\mathrm{AOM})^{3-5}\end{array}$ & $\begin{array}{l}\text { - AOM is the most } \\
\text { common } \\
\text { childhood } \\
\text { infection for which } \\
\text { antibiotics are } \\
\text { prescribed. } \\
\text { - } 4-10 \% \text { of children } \\
\text { with AOM treated } \\
\text { with antibiotics } \\
\text { experience adverse } \\
\text { effects. } .\end{array}$ & $\begin{array}{l}\text { Definitive diagnosis requires either } \\
\text { - Moderate or severe bulging of } \\
\text { tympanic membrane (TM) or new } \\
\text { onset otorrhea not due to otitis } \\
\text { externa. } \\
\text { - Mild bulging of the TM AND recent } \\
\text { (<48h) onset of otalgia (holding, } \\
\text { tugging, rubbing of the ear in a } \\
\text { nonverbal child) or intense erythema } \\
\text { of the TM. } \\
\text { AOM should not be diagnosed in children } \\
\text { without middle ear effusion (based on } \\
\text { pneumatic otoscopy and/or tympanometry). }\end{array}$ & $\begin{array}{l}\text { - Mild cases with unilateral symptoms in } \\
\text { children } 6 \text { - } 23 \text { months of age or } \\
\text { unilateral or bilateral symptoms in } \\
\text { children }>2 \text { years may be appropriate } \\
\text { for watchful waiting based on shared } \\
\text { decision-making. } \\
\text { - Amoxicillin remains first line therapy for } \\
\text { children who have not received } \\
\text { amoxicillin within the past } 30 \text { days. } \\
\text { - Amoxicillin/clavulanate is recommended } \\
\text { if amoxicillin has been taken within the } \\
\text { past } 30 \text { days, if concurrent purulent } \\
\text { conjunctivitis is present, or if the child } \\
\text { has a history of recurrent AOM } \\
\text { unresponsive to amoxicillin. } \\
\text { For children with a non-type I } \\
\text { hypersensitivity to penicillin: cefdinir, } \\
\text { cefuroxime, cefpodoxime, or ceftriaxone } \\
\text { may be appropriate choices. } \\
\text { Prophylactic antibiotics are not } \\
\text { recommended to reduce the frequency } \\
\text { of recurrent AOM. }\end{array}$ \\
\hline
\end{tabular}




\begin{tabular}{|c|c|c|c|}
\hline & & & $\begin{array}{l}\text { - For further recommendations on } \\
\text { alternative antibiotic regimens, consult } \\
\text { the American Academy of Pediatrics } \\
\text { guidelines. }-\end{array}$ \\
\hline Pharyngitis 4,6 & $\begin{array}{l}\text { Recent guidelines } \\
\text { aim to minimize } \\
\text { unnecessary } \\
\text { antibiotic exposure } \\
\text { by emphasizing } \\
\text { appropriate use of } \\
\text { rapid antigen } \\
\text { detection test } \\
\text { (RADT) testing and } \\
\text { subsequent } \\
\text { treatment. } \\
\text { During the winter } \\
\text { and spring, up to } \\
\text { 20\% of } \\
\text { asymptomatic } \\
\text { children can be } \\
\text { colonized with } \\
\text { group A beta- } \\
\text { hemolytic } \\
\text { streptococci (GAS), } \\
\text { leading to more } \\
\text { false positives } \\
\text { from RADT-testing }\end{array}$ & 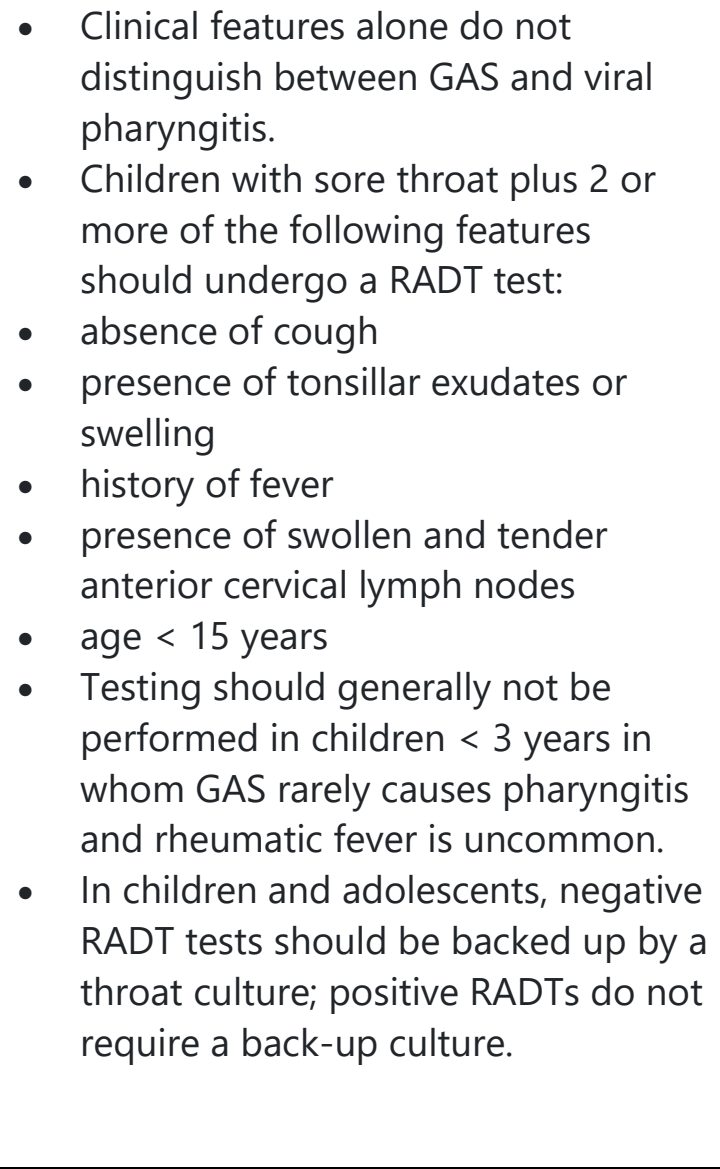 & $\begin{array}{l}\text { - Amoxicillin and penicillin } \mathrm{V} \text { remain first- } \\
\text { line therapy. } \\
\text { For children with a non-type I } \\
\text { hypersensitivity to penicillin: cephalexin, } \\
\text { cefadroxil, clindamycin, clarithromycin, } \\
\text { or azithromycin are recommended. } \\
\text { - For children with an immediate type I } \\
\text { hypersensitivity to penicillin: } \\
\text { clindamycin, clarithyomycin, or } \\
\text { azithroymycin are recommended. } \\
\text { Recommended treatment course for all } \\
\text { oral beta lactams is } 10 \text { days. }\end{array}$ \\
\hline
\end{tabular}




\begin{tabular}{|c|c|c|c|}
\hline & $\begin{array}{l}\text { and increases in } \\
\text { unnecessary } \\
\text { antibiotic } \\
\text { exposure. } \\
\text { - Streptococcal } \\
\text { pharyngitis is } \\
\text { primarily a disease } \\
\text { of children 5-15 } \\
\text { years old and is } \\
\text { rare in children < } 3 \\
\text { years. }\end{array}$ & & \\
\hline $\begin{array}{l}\text { Common cold or } \\
\text { non-specific } \\
\text { upper } \\
\text { respiratory tract } \\
\text { infection (URI) }\end{array}$ & $\begin{array}{l}\text { - The course of } \\
\text { most } \\
\text { uncomplicated } \\
\text { viral URIs is } 5-7 \\
\text { days. Colds } \\
\text { usually last around } \\
10 \text { days. } \\
\text { - At least } 200 \\
\text { viruses can cause } \\
\text { the common cold. }\end{array}$ & $\begin{array}{l}\text { - Viral URIs are often characterized by } \\
\text { nasal discharge and congestion or } \\
\text { cough. Usually nasal discharge } \\
\text { begins as clear and changes } \\
\text { throughout the course of the illness. } \\
\text { - Fever, if present, occurs early in the } \\
\text { illness. }\end{array}$ & $\begin{array}{l}\text { Management of the common cold, } \\
\text { nonspecific URI, and acute cough illness } \\
\text { should focus on symptomatic relief. } \\
\text { Antibiotics should not be prescribed for } \\
\text { these conditions. } \\
\text { - There is potential for harm and no } \\
\text { proven benefit from over-the-counter } \\
\text { cough and cold medications in children } \\
<6 \text { years. These substances are among } \\
\text { the top } 20 \text { substances leading to death } \\
\text { in children < } 5 \text { years. } \\
\text { Low-dose inhaled corticosteroids and } \\
\text { oral prednisolone do not improve } \\
\text { outcomes in children without asthma. }\end{array}$ \\
\hline
\end{tabular}




\begin{tabular}{|c|c|c|c|}
\hline Bronchiolitis & $\begin{array}{l}\text { Bronchiolitis is the } \\
\text { most common } \\
\text { lower respiratory } \\
\text { tract infection in } \\
\text { infants. } \\
\text { - It is most often } \\
\text { caused by } \\
\text { respiratory } \\
\text { syncytial virus but } \\
\text { can be caused by } \\
\text { many other } \\
\text { respiratory viruses. }\end{array}$ & $\begin{array}{l}\text { - Bronchiolitis occurs in children }<24 \\
\text { months and is characterized by } \\
\text { rhinorrhea, cough, wheezing, } \\
\text { tachypnea, and/ or increased } \\
\text { respiratory effort. } \\
\text { Routine laboratory tests and } \\
\text { radiologic studies are not } \\
\text { recommended, but a chest x-ray may } \\
\text { be warranted in atypical disease } \\
\text { (absence of viral symptoms, severe } \\
\text { distress, frequent recurrences, lack of } \\
\text { improvement). }\end{array}$ & $\begin{array}{l}\text { - Usually patients worsen between 3-5 } \\
\text { days, followed by improvement. } \\
\text { - Antibiotics are not helpful and should } \\
\text { not be used. } \\
\text { - Nasal suctioning is mainstay of therapy. } \\
\text { epinephrine should be administered to } \\
\text { infants and children with bronchiolitis } \\
\text { who are not hospitalized. } \\
\text { There is no evidence to support routine } \\
\text { suctioning of the lower pharynx or } \\
\text { larynx (deep suctioning). } \\
\text { There is no role for corticosteroids, } \\
\text { ribavirin, or chest physiotherapy in the } \\
\text { management of bronchiolitis. }\end{array}$ \\
\hline
\end{tabular}

CDC Outpatient Pediatric Treatment Recommendations (2017).

Retrieved from: https://www.cdc.gov/antibiotic-use/community/for-hcp/outpatient-hcp/pediatric-treatment-rec.html 


\section{Appendix B}

\section{CDC Antibiotic Pamphlet}

Why does taking antibiotics lead to antibiotic resistance?

Any time antibiotics are used, they can cause side effects and lead to antibiotic resistance. Antibiotic resistance is one of the most urgent threats to the public's health. Always remember:

1. Antibiotic resistance does not mean the

body is becoming resistant to antibiotics: it

is that bacteria have become resistant to the antibiotics designed to kill them.

2. When bacteria become resistant, antibiotics cannot fight them, and the bacteriamultiply.

3. Some resistant bacteria can be harder to treat and can spread to other people.

More than 2.8 million antibiotic-resistant infections occur in the United States each year, and more than 35,000 people die as a result.

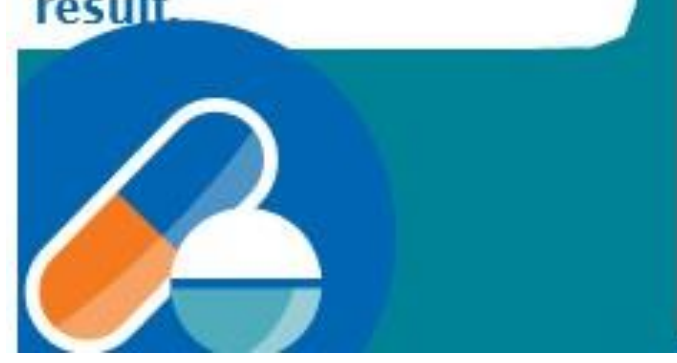

What is the right way to take antibiotics?

Ifyou need antibiotics, take them exactly as prescribed.

Improving the way healthcare professionals prescribe antibiotics, and the way we take antibiotics, helps keep us healthy now, helps fight antibiotic resistance, and ensures that these life-saving drugs will be available for

future generations.

Talk with your doctor if you have any questions about your antibiotics, or if you develop any side effects, especially diarthea, since that could be Clostridioides difficile infection (also called C. difficile or $C$. diff), which needs to be treated. $C$. diff can lead to severe colon damage and death.

\section{What are the side effects?}

Common side effects range from minor to very severe health problems and can include:

- Rash

- Dizziness

- Nausea

- Diarrhea

- Yeast infections

More serious side effects can include:

- Clostridioides difficile infection

- Severe and life-threatening allergic reactions

To learn more about antibiotic prescribing and use, visit www.cdc.gov/antibiotic-use.

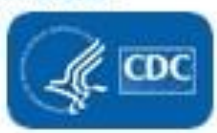

\section{Antibiotics Aren't Always the Answer.}
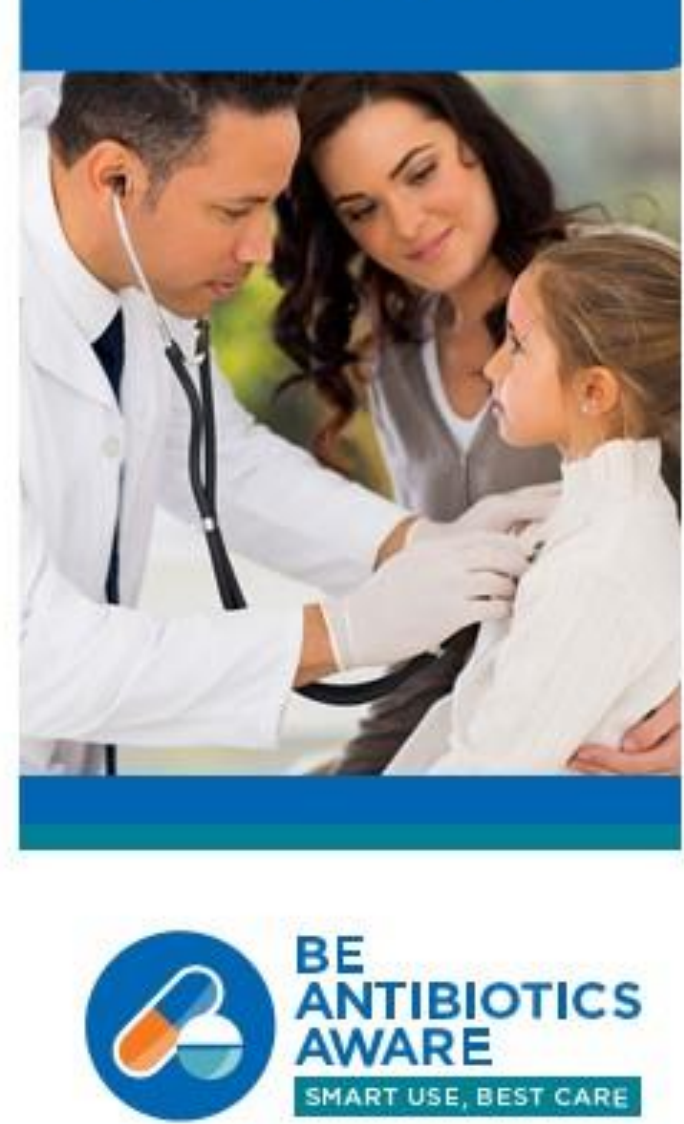

BE ANTIBIOTICS AWARE SMART USE, BEST CARE 


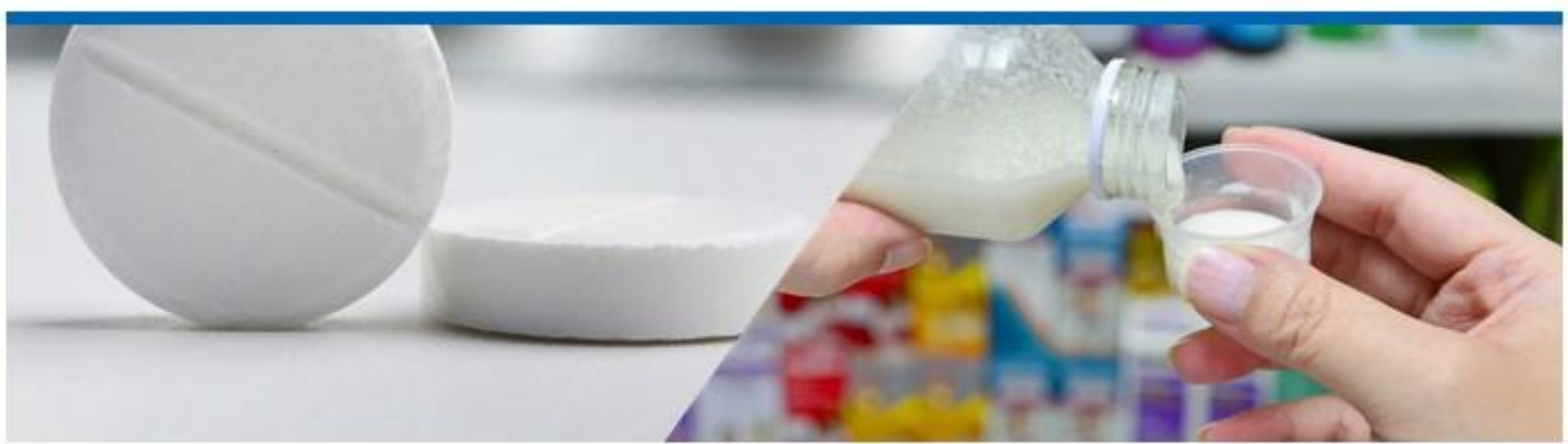

\section{Why is it important to} Be Antibiotics Aware?

Antibiotics save lives. When a patient needs antibiotics, the benefits outweigh the risks of side effects or antibiotic resistance.

When antibiotics aren't needed, they won't help you, and the side effects could still hurt you. Reactions from antibiotics cause 1 out of 5 medication-related visits to the emergency department.

\section{In children, reactions} from antibiotics are the most common cause of medication-related emergency department visits.

\section{What do antibiotics treat?}

Antibiotics areonly needed fortreating certain infections caused by bacteria. Antibiotics are critical tools for treating common infections.

such as pneumonia, and for life-threatening conditions including sepsis, the body's extreme response to an infection.

\section{What don't antibiotics treat?}

Antibiotics do not work on viruses, such as colds and flu, or runny noses, even if the mucus is thick, yellow or green. Antibiotics also won't help some common bacterial infections including most cases of bronchitis, many sinus infections, and some ear infections.

\section{How can I stayhealthy?}

You can stay healthy and keep others healthy by:

- Cleaning hands

- Covering coughs

- Staying home when sick

- Getting recommended vaccines, for the flu, for example

Talk to your doctor or nurse about steps you can take to prevent infections.

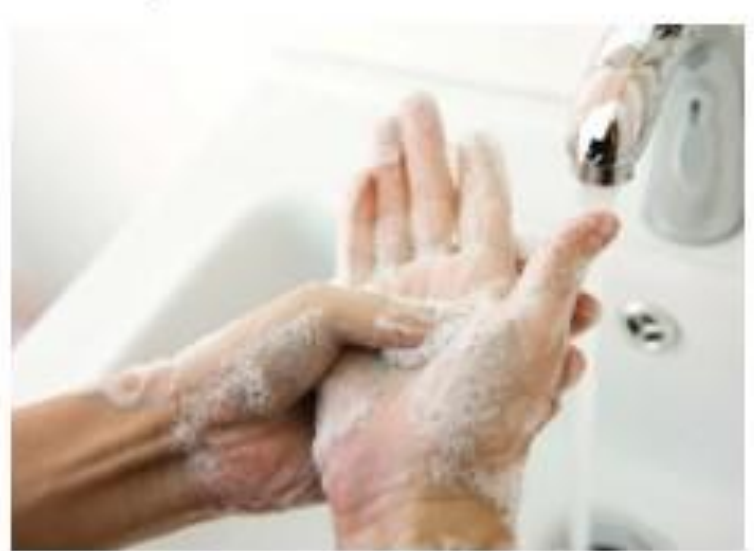


Appendix C

\section{CDC Antibiotic Poster}

\section{Viruses or Bacteria What's got you sick?}

Antibiotics are only needed for treating certain infections caused by bacteria. Viral illnesses cannot be treated with antibiotics. When an antibiotic is not prescribed, ask

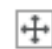

your healthcare professional for tips on how to relieve symptoms and feel better.

\begin{tabular}{|c|c|c|c|c|}
\hline \multirow{2}{*}{ Common Condition } & \multicolumn{3}{|c|}{ Common Cause } & \multirow{2}{*}{$\begin{array}{l}\text { Are } \\
\text { Antibiotics } \\
\text { Needed? }\end{array}$} \\
\hline & Bacteria & $\begin{array}{l}\text { Bacteria } \\
\text { or Virus }\end{array}$ & Virus & \\
\hline Strep throat & $\checkmark$ & & & Yes \\
\hline Whooping cough & $\checkmark$ & & & Yes \\
\hline Urinary tract infection & $\checkmark$ & & & Yes \\
\hline Sinus infection & & $\checkmark$ & & Maybe \\
\hline Middle ear infection & & $\checkmark$ & & Maybe \\
\hline $\begin{array}{l}\text { Bronchitis/chest cold (in } \\
\text { otherwise hesithy children } \\
\text { ond odults) }\end{array}$ & & $\checkmark$ & & $\mathrm{Na}^{*}$ \\
\hline Common cold/runny nose & & & $\checkmark$ & No \\
\hline Sore throat (except strep) & & & $\checkmark$ & No \\
\hline Flu & & & $\checkmark$ & No \\
\hline
\end{tabular}

BE

ANTIBIOTICS

AWARE
Tolearn more about antibiotic prescribing and use, visit www.cdc.gov/antibiotic-use. 


\section{Appendix D}

Upper Respiratory Tract Antibiotic Tracking Tool

Provider \#:

\begin{tabular}{|l|l|l|}
\hline Time Interval & Time Point 1 & Time Point 2 \\
\hline Numerator: \# URI visits antibiotic & & \\
\hline Denominator: Total \# of URI visits & & \\
\hline $\begin{array}{l}\text { Percent receiving unnecessary } \\
\text { antibiotics= } \\
\text { (Numerator/Denominator) x } 100\end{array}$ & & \\
& & \\
\hline
\end{tabular}

Adapted from Telligen, the Quality Innovation Network National Coordinating Center, under contract with the Centers for Medicare \& Medicaid Services (CMS) (2017). Retrieved from https://healthinsight.org/tools-and-resources/send/167-outpatient-antibiotic-stewardship/1381-audit-worksheet-for-viral-upper-respiratory-infections 


\section{Appendix E}

\section{Antibiotic Stewardship Provider Survey}

Please answer the following questions:

1 = Strongly Disagree; 2 = Disagree; 3 = Neither; 4 = Agree; 5 = Strongly Agree

1. Antimicrobial stewardship is important.
1
2
3
4
5

2. Antibiotic resistance and inappropriate prescribing is a national problem.

2

3

4

5

3. Antibiotic resistance and inappropriate prescribing is a problem in the clinic.

2

3

4

5

4. As a provider it is easy to make antimicrobial stewardship a priority.

1 2 3 4 5

5. It is more important for the facility to focus on antimicrobial stewardship than it is for the provider.

1

2

3

5

6. I am often pressured by patients to prescribe an antibiotic when not indicated.
4

5 
7. Patient education is key to avoiding unwarranted antibiotic prescribing.

1

2

4

5

Modified, with permission from CDC MITIGATE toolkit (2018). Retrieved from

https://qioprogram.org/sites/default/files/editors/141/MITIGATE_TOOLKIT_final_approved\%281\%29_508.pdf

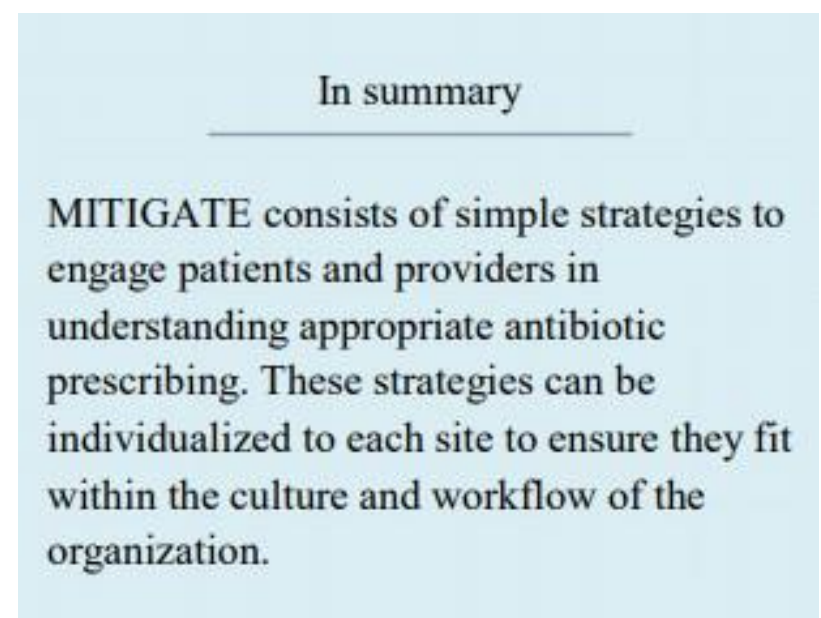

(CDC, 2018) 


\section{Appendix F}

\section{Johns Hopkins Nursing Evidence-Based Practice}

\section{Appendix D}

\section{Evidence Level and Quality Guide}

\begin{tabular}{|c|c|}
\hline E & ity Ratings \\
\hline \multirow{5}{*}{$\begin{array}{l}\text { Level I } \\
\text { Experimental study, randomized cc } \\
(\mathrm{RCT}) \\
\text { Explanatory mixed method design } \\
\text { only a level I quaNtitative study } \\
\text { Systematic review of RCTs, with or } \\
\text { analysis }\end{array}$} & \multirow{5}{*}{$\begin{array}{l}\text { QuaNtitative Studies } \\
\text { A High quality: Consistent, generalizable results; sufficient sample size for the study design; adequate } \\
\text { control; definitive conclusions; consistent recommendations based on comprehensive literature review that } \\
\text { includes thorough reference to scientific evidence. } \\
\text { B Good quality: Reasonably consistent results; sufficient sample size for the study design; some control, } \\
\text { fairly definitive conclusions; reasonably consistent recommendations based on fairly comprehensive } \\
\text { literature review that includes some reference to scientific evidence. } \\
\text { C Low quality or major flaws: Little evidence with inconsistent results; insufficient sample size for the } \\
\text { study design; conclusions cannot be drawn. }\end{array}$} \\
\hline & \\
\hline & \\
\hline & \\
\hline & \\
\hline \multirow{7}{*}{$\begin{array}{l}\text { Level II } \\
\text { Quasi-experimental study } \\
\text { Explanatory mixed method design that includes } \\
\text { only a level II quaNtitative study } \\
\text { Systematic review of a combination of RCTs and } \\
\text { quasi-experimental studies, or quasi- } \\
\text { experimental studies only, with or without meta- } \\
\text { analysis }\end{array}$} & \multirow{14}{*}{$\begin{array}{l}\text { QuaLitative Studies } \\
\text { No commonly agreed-on principles exist for judging the quality of quaLitative studies. It is a subjective } \\
\text { process based on the extent to which study data contributes to synthesis and how much information is known } \\
\text { about the researchers' efforts to meet the appraisal criteria. } \\
\text { For meta-synthesis, there is preliminary agreement that quality assessments of individual studies should be } \\
\text { made before synthesis to screen out poor-quality studies }{ }^{1} \text {. } \\
\text { A/B High/Good quality is used for single studies and meta-syntheses) }{ }^{2} \text {. } \\
\text { The report discusses efforts to enhance or evaluate the quality of the data and the overall inquiry in } \\
\text { sufficient detail; and it describes the specific techniques used to enhance the quality of the inquiry. } \\
\text { Evidence of some or all of the following is found in the report: } \\
\text { - Transparency: Describes how information was documented to justify decisions, how data were } \\
\text { reviewed by others, and how themes and categories were formulated. } \\
\text { - Diligence: Reads and rereads data to check interpretations; seeks opportunity to find multiple } \\
\text { sources to corroborate evidence. } \\
\text { - Verification: The process of checking, confirming, and ensuring methodologic coherence. } \\
\text { - Self-reflection and scrutiny: Being continuously aware of how a researcher's experiences, } \\
\text { background, or prejudices might shape and bias analysis and interpretations. } \\
\text { - Participant-driven inquiry: Participants shape the scope and breadth of questions; analysis and } \\
\text { interpretation give voice to those who participated. } \\
\text { - Insightful interpretation: Data and knowledge are linked in meaningful ways to relevant literature. } \\
\text { C Low quality studies contribute little to the overall review of findings and have few, if any, of the features } \\
\text { listed for high/good quality. }\end{array}$} \\
\hline & \\
\hline & \\
\hline & \\
\hline & \\
\hline & \\
\hline & \\
\hline \multirow{4}{*}{$\begin{array}{l}\text { Level III } \\
\text { Nonexperimental study } \\
\text { Systematic review of a combination of RCTs, } \\
\text { quasi-experimental and nonexperimental studies, } \\
\text { or nonexperimental studies only, with or without } \\
\text { meta-analysis }\end{array}$} & \\
\hline & \\
\hline & \\
\hline & \\
\hline $\begin{array}{l}\text { Exploratory, convergent, or multiphasic mixed } \\
\text { methods studies }\end{array}$ & \\
\hline & \\
\hline & \\
\hline
\end{tabular}




\section{Appendix G}

\section{Summary of Primary Research Evidence}

\begin{tabular}{|c|c|c|c|c|c|c|}
\hline Citation & $\begin{array}{c}\text { Design, Level } \\
\text { Quality } \\
\text { Grade }\end{array}$ & $\begin{array}{c}\text { Sample } \\
\text { Sample size }\end{array}$ & $\begin{array}{l}\text { Intervention } \\
\text { Comparison } \\
\text { (Definitions } \\
\text { should include } \\
\text { any specific } \\
\text { research tools } \\
\text { used along with } \\
\text { reliability \& } \\
\text { validity) }\end{array}$ & $\begin{array}{l}\text { Theoretical } \\
\text { Foundation }\end{array}$ & $\begin{array}{l}\text { Outcome } \\
\text { Definition }\end{array}$ & $\begin{array}{c}\text { Usefulness } \\
\text { Results } \\
\text { Key Findings }\end{array}$ \\
\hline $\begin{array}{l}\text { Barlam, T.F., } \\
\text { Cosgroave, S.E., } \\
\text { Abbo, L.M., } \\
\text { MacDougall, C., } \\
\text { Schuetz, A.N., \& } \\
\text { Septimus, E.J., } \\
\text {..Trivedi, K.K. } \\
\text { (2016). Implementing } \\
\text { an antibiotic } \\
\text { stewardship program: } \\
\text { guidelines by the } \\
\text { infectious diseases' } \\
\text { society of America and } \\
\text { the society for } \\
\text { healthcare } \\
\text { epidemiology of } \\
\text { America. Clinical } \\
\text { Infectious Disease, } 62 \text {, } \\
\text { e51. }\end{array}$ & $\begin{array}{l}\text { The study } \\
\text { was a } \\
\text { retrospective } \\
\text { analysis } \\
\text { Evidence } \\
\text { Level: } 2 \\
\text { Quality: B }\end{array}$ & $\begin{array}{l}17,235 \text { visits } \\
\text { total. } \\
\text { Of those } 9,491 \\
\text { were in a } \\
\text { community } \\
\text { practice. } \\
\text { Emergency } \\
\text { Department } \\
\text { visit total } 7,744\end{array}$ & $\begin{array}{l}\text { A retrospective } \\
\text { analysis was } \\
\text { completed } \\
\text { comparing } \\
\text { antibiotic } \\
\text { prescribing } \\
\text { trends in } \\
\text { community- } \\
\text { based office } \\
\text { practices as well } \\
\text { as hospital } \\
\text { emergency } \\
\text { departments. } \\
\text { Other variables } \\
\text { that were focused } \\
\text { on were patient's } \\
\text { education level, } \\
\text { literacy, as well } \\
\text { as poverty level }\end{array}$ & $\begin{array}{l}\text { No theoretical } \\
\text { framework }\end{array}$ & $\begin{array}{l}\text { Community } \\
\text { practices were } \\
\text { much more likely } \\
\text { to overprescribe } \\
\text { when compared to } \\
\text { Emergency } \\
\text { Departments }\end{array}$ & $\begin{array}{c}\text { Education was an effective } \\
\text { approach to achieving } \\
\text { stewardship. Multiple factors } \\
\text { should be considered when } \\
\text { educating patients such as there } \\
\text { education and health literacy } \\
\text { levels. }\end{array}$ \\
\hline
\end{tabular}




\begin{tabular}{|c|c|c|c|c|c|c|}
\hline $\begin{array}{l}\text { Biezen, R., Brijnath, } \\
\text { B., Grando, D., \& } \\
\text { Mazza, D. (2017). } \\
\text { Management of } \\
\text { respiratory tract } \\
\text { infections in young } \\
\text { children- A qualitative } \\
\text { study of primary care } \\
\text { providers' } \\
\text { perspectives. Nature } \\
\text { Partner Journal, } \\
\text { 27(15). 1-7. }\end{array}$ & $\begin{array}{c}\text { Cross } \\
\text { sectional } \\
\text { qualitative } \\
\text { research } \\
\text { design } \\
\text { Evidence } \\
\text { Level: } 3 \\
\text { Quality: B }\end{array}$ & $\begin{array}{l}30 \text { primary care } \\
\text { providers }\end{array}$ & $\begin{array}{l}\text { In-depth } \\
\text { interviews were } \\
\text { conducted to } \\
\text { evaluate } \\
\text { effectiveness of } \\
\text { clinical } \\
\text { guidelines and } \\
\text { patient (parent } \\
\text { education) at } \\
\text { decreasing } \\
\text { antibiotic } \\
\text { prescribing when } \\
\text { not indicated. }\end{array}$ & $\begin{array}{l}\text { Theoretical } \\
\text { domains } \\
\text { framework }\end{array}$ & $\begin{array}{l}\text { Guidelines proven } \\
\text { to be helpful with } \\
\text { the addition of } \\
\text { patient/parent } \\
\text { education. } \\
\text { Difficult to stick } \\
\text { with guidelines } \\
\text { when pressured by } \\
\text { parent to prescribe } \\
\text { antibiotics }\end{array}$ & $\begin{array}{l}\text { Guidelines and education are } \\
\text { effective approaches to } \\
\text { managing antibiotic prescribing. } \\
\text { It was noted that it can be } \\
\text { difficult to stick with guidelines } \\
\text { when parents pressure providers } \\
\text { to prescribe antibiotics. }\end{array}$ \\
\hline $\begin{array}{l}\text { Clegg, H.W., Bean, R. } \\
\text { A., Ezzo, S. J., Hoth, } \\
\text { A. N., Sheedy, D. J., \& } \\
\text { Anderson, W.E., } \\
\text { (2019). Impact of } \\
\quad \text { education and } \\
\text { peer comparison on } \\
\text { antibiotic prescribing } \\
\text { for pediatric } \\
\text { respiratory tract } \\
\text { infections. Pediatric } \\
\text { Quality and Safety, } \\
\text { 4(4). }\end{array}$ & $\begin{array}{l}\text { The study } \\
\text { was a pre } \\
\text { post, quasi- } \\
\text { experimental, } \\
\text { quality } \\
\text { improvement } \\
\text { initiative } \\
\text { Evidence } \\
\text { Level: } 2 \\
\text { Quality: B }\end{array}$ & $\begin{array}{l}22 \text { pediatric } \\
\text { clinics } \\
\text { consisting of } \\
112 \text { physicians } \\
\text { and } 53 \text { advance } \\
\text { practice } \\
\text { clinicians }\end{array}$ & $\begin{array}{l}\text { The intervention } \\
\text { consisted of } \\
\text { educational } \\
\text { material provided } \\
\text { to all clinicians } \\
\text { which included } \\
\text { clinical } \\
\text { guidelines, 1- hr } \\
\text { educational } \\
\text { sessions, } \\
\text { accompanied by } \\
\text { individual audit } \\
\text { and feedback }\end{array}$ & $\begin{array}{l}\text { Theoretical } \\
\text { framework: } \\
\text { Model for } \\
\text { Improvement }\end{array}$ & $\begin{array}{l}\text { Antibiotics } \\
\text { prescribed to treat } \\
\text { respiratory tract } \\
\text { infections } \\
\text { decreased from } \\
57 \% \text { to } 34 \%\end{array}$ & $\begin{array}{l}\text { The utilization of guidelines, } \\
\text { education, and clinician } \\
\text { feedback resulted in reductions } \\
\text { in antibiotics prescribed for } \\
\text { respiratory tract infections. }\end{array}$ \\
\hline $\begin{array}{l}\text { Feiring, E., \& Walter, } \\
\text { B. (2017). } \\
\text { Antimicrobial } \\
\text { stewardship: a } \\
\text { qualitative study of the } \\
\text { development of } \\
\text { national guidelines for } \\
\text { antibiotic use in }\end{array}$ & $\begin{array}{l}\text { The study } \\
\text { was a } \\
\text { qualitative } \\
\text { thematic } \\
\text { analysis }\end{array}$ & $\begin{array}{l}\text { Systematic } \\
\text { reading of } \\
\text { archival data } \\
8 \text { clinicians } \\
\text { interviewed }\end{array}$ & $\begin{array}{l}\text { Archival data } \\
\text { was collected } \\
\text { and reviewed to } \\
\text { determine the } \\
\text { guideline } \\
\text { development } \\
\text { process. } 8 \\
\text { clinicians were }\end{array}$ & $\begin{array}{l}\text { Theoretical } \\
\text { Framework: } \\
\text { inspired by the } \\
\text { AGREE II } \\
\text { instrument and } \\
\text { accountability } \\
\text { for } \\
\text { reasonableness }\end{array}$ & $\begin{array}{l}\text { The clinicians in } \\
\text { this study found } \\
\text { the antibiotic } \\
\text { stewardship } \\
\text { guidelines } \\
\text { acceptable if they } \\
\text { agreed with the } \\
\text { scope \& purpose, }\end{array}$ & $\begin{array}{l}\text { This study identified some } \\
\text { key features that when } \\
\text { incorporated when developing } \\
\text { antibiotic stewardship } \\
\text { guidelines, it increases } \\
\text { clinician's feelings regarding } \\
\text { the legitimacy, and } \\
\text { acceptability of the guidelines }\end{array}$ \\
\hline
\end{tabular}




\begin{tabular}{|c|c|c|c|c|c|c|}
\hline $\begin{array}{l}\text { hospitals. BioMed } \\
\text { Central Health } \\
\text { Services Research } \\
\text { 17,(747). Doi: } \\
\text { 10.1186/s12913-017- } \\
2683-4\end{array}$ & $\begin{array}{l}\text { Evidence } \\
\text { Level: } 3 \\
\text { Quality: B }\end{array}$ & & $\begin{array}{l}\text { interviewed to } \\
\text { determine } \\
\text { contributing } \\
\text { factors that help } \\
\text { to validate the } \\
\text { legitimacy of } \\
\text { guidelines that } \\
\text { are developed. }\end{array}$ & & $\begin{array}{l}\text { developed by key } \\
\text { stakeholders, the } \\
\text { guidelines have } \\
\text { specific } \\
\text { recommendations } \\
\text { that are easily } \\
\text { identifiable, tools } \\
\text { to help } \\
\text { implement the } \\
\text { guidelines. }\end{array}$ & $\begin{array}{l}\text { that results in a greater level } \\
\text { of utilization compliance. }\end{array}$ \\
\hline $\begin{array}{l}\text { Frisina, P., Pletcher, J., } \\
\text { Munene, E., \& } \\
\text { Kolligian, J., (2016). } \\
\text { Antibiotic stewardship } \\
\text { for acute bronchitis: a } \\
\text { quality improvement } \\
\text { study in university } \\
\text { healthcare. BMJ } \\
\text { 25(12). }\end{array}$ & $\begin{array}{l}\text { QI } \\
\text { interventions } \\
\text { were } \\
\text { implemented } \\
\text { utilizing } \\
\text { clinical } \\
\text { guidelines } \\
\text { Evidence } \\
\text { Level: 3 } \\
\text { Quality: B }\end{array}$ & $\begin{array}{l}66 \text { university } \\
\text { based } \\
\text { healthcare } \\
\text { centers }\end{array}$ & $\begin{array}{l}\text { Baseline chart } \\
\text { reviews were } \\
\text { conducted to } \\
\text { determine the } \\
\text { amount of } \\
\text { antibiotics } \\
\text { prescribed for } \\
\text { acute } \\
\text { bronchitis. QI } \\
\text { interventions } \\
\text { were } \\
\text { implemented } \\
\text { utilizing } \\
\text { clinical } \\
\text { guidelines } \\
\text { when treating } \\
\text { acute } \\
\text { bronchitis, as } \\
\text { well as peer } \\
\text { chart review to } \\
\text { assist in } \\
\text { guideline } \\
\text { compliance. }\end{array}$ & $\begin{array}{l}\text { Theoretical } \\
\text { framework: } \\
\text { IHI-Model for } \\
\text { improvement }\end{array}$ & $\begin{array}{l}\text { QI-interventions } \\
\text { decreased } \\
\text { antibiotic } \\
\text { prescribing rates } \\
\text { from } 80 \% \\
\text { initially to a level } \\
\text { of } 5 \%\end{array}$ & $\begin{array}{l}\text { The implementation of } \\
\text { antibiotic guidelines can } \\
\text { decrease antibiotic } \\
\text { prescription rates with the } \\
\text { utilization of staff and patient } \\
\text { education as well as peer } \\
\text { chart review. }\end{array}$ \\
\hline $\begin{array}{l}\text { Gifford, J., Vaeth, E., } \\
\text { Richards, K., Siddiqui, } \\
\text { T., Gill, C., Eilson, L., }\end{array}$ & $\begin{array}{l}\text { Retrospective, } \\
\text { observational } \\
\text { interventional } \\
\text { study; quasi- } \\
\end{array}$ & $\begin{array}{l}\text { Sample: } \\
\text { Outpatients } \\
\text { with acute }\end{array}$ & $\begin{array}{l}\text { Clinical decision } \\
\text { support system } \\
\text { was interposed } \\
\text { into EMR to }\end{array}$ & $\begin{array}{l}\text { No theoretical } \\
\text { framework }\end{array}$ & $\begin{array}{l}\text { After the clinical } \\
\text { decision-support } \\
\text { system was } \\
\text { implemented there }\end{array}$ & $\begin{array}{l}\text { Results were moderately helpful } \\
\text { in the sense having the clinical } \\
\text { decision support system } \\
\text { embedded into the EMR did }\end{array}$ \\
\hline
\end{tabular}




\begin{tabular}{|c|c|c|c|c|c|c|}
\hline $\begin{array}{l}\text { \& DeLisle, S., (2017). } \\
\text { Decision support } \\
\text { during electronic } \\
\text { prescription to stem } \\
\text { antibiotic overuse for } \\
\text { acute respiratory } \\
\text { infections: a long- } \\
\text { term, quasi- } \\
\text { experimental study. } \\
\text { BMC Infectious } \\
\text { Diseases. } 17(528), 1-8 . \\
\text { Doi:10.1186/s } 12879- \\
\quad 017-2602-7\end{array}$ & $\begin{array}{l}\text { experimental } \\
\text { design } \\
\text { Evidence } \\
\text { Level: } 2 \\
\text { Quality: B }\end{array}$ & $\begin{array}{l}\text { respiratory } \\
\text { infection visits } \\
\text { Sample size: } \\
1131\end{array}$ & $\begin{array}{l}\text { assist with } \\
\text { appropriateness } \\
\text { of antibiotic } \\
\text { prescribing } \\
\text { specifically } \\
\text { focusing in on } \\
\text { azithromycin and } \\
\text { fluoroquinolones. }\end{array}$ & & $\begin{array}{l}\text { was no reduction } \\
\text { in azithromycin } \\
\text { prescribing and a } \\
\text { reduction }(88.6 \% \\
\text { to } 51.3 \%) \text { in } \\
\text { fluoroquinolone } \\
\text { prescribing. }\end{array}$ & $\begin{array}{l}\text { seem to assist with a reduction in } \\
\text { antibiotic prescribing however } \\
\text { these reductions were oddly only } \\
\text { seen in the prescribing of } \\
\text { fluoroquinolones and not for } \\
\text { azithromycin. }\end{array}$ \\
\hline $\begin{array}{l}\text { Gulliford, M.C., } \\
\text { Moore, M.V., Little, } \\
\text { P., Hay, A.D., Fox, R., } \\
\text { Prevost, T., .. Asworth, } \\
\text { M. (2016). Safety of } \\
\text { reduced antibiotic } \\
\text { prescribing for self- } \\
\text { limiting respiratory } \\
\text { tract infections in } \\
\text { primary care: cohort } \\
\text { study using electronic } \\
\text { health records. BMJ, } \\
\text { 354(i3410). }\end{array}$ & $\begin{array}{l}\text { Cohort } \\
\text { Study } \\
\text { Evidence } \\
\text { Level: } 1 \\
\text { Quality: A }\end{array}$ & $\begin{array}{l}610 \text { clinical } \\
\text { practices } \\
45.5 \text { million } \\
\text { people }\end{array}$ & $\begin{array}{l}\text { Policy guidelines } \\
\text { were } \\
\text { implemented for } \\
\text { half the clinical } \\
\text { practices with } \\
\text { education being } \\
\text { given to all } \\
\text { patients. }\end{array}$ & $\begin{array}{l}\text { No theoretical } \\
\text { framework }\end{array}$ & $\begin{array}{l}\text { Overall reduction } \\
\text { in antibiotic } \\
\text { prescribing was } \\
\text { noted in those } \\
\text { utilizing policy } \\
\text { guidelines. }\end{array}$ & $\begin{array}{l}\text { Education alone does not assist } \\
\text { in reducing antibiotic } \\
\text { prescribing. Education with the } \\
\text { addition of treatment policy } \\
\text { guidelines helps to reduce } \\
\text { overall antibiotic prescribing and } \\
\text { also minimizes potential } \\
\text { complications that can be } \\
\text { associated with antibiotic use. }\end{array}$ \\
\hline $\begin{array}{l}\text { Meeker, D., Linder, } \\
\text { J.A., Fox, C.R., } \\
\text { Friedberg, M.W., } \\
\text { Persell, S.D., } \\
\text { Goldstein, N.J., .. } \\
\text { Doctor, J.N. (2016). } \\
\text { Effects of behavioral } \\
\text { interventions on } \\
\text { inappropriate } \\
\text { antibiotic prescribing }\end{array}$ & $\begin{array}{l}\text { Evidence } \\
\text { Level: } 2 \\
\text { Quality: B }\end{array}$ & $\begin{array}{l}47 \text { primary } \\
\text { care practices. } \\
248 \text { clinicians. }\end{array}$ & $\begin{array}{l}\text { The intervention } \\
\text { was treatment } \\
\text { guidelines that } \\
\text { popped up within } \\
\text { the electronic } \\
\text { medical records } \\
\text { when the } \\
\text { diagnosis of } \\
\text { upper respiratory } \\
\text { infection was }\end{array}$ & $\begin{array}{l}\text { No theoretical } \\
\text { framework }\end{array}$ & $\begin{array}{l}\text { Both groups } \\
\text { showed a } \\
\text { reduction in } \\
\text { antibiotic } \\
\text { prescribing for } \\
\text { acute respiratory } \\
\text { illnesses. The } \\
\text { intervention } \\
\text { group had the } \\
\text { most reduction in }\end{array}$ & $\begin{array}{l}\text { Educating providers proved to } \\
\text { be helpful in reducing the } \\
\text { amount of antibiotic } \\
\text { prescribed for acute } \\
\text { respiratory illnesses. }\end{array}$ \\
\hline
\end{tabular}




\begin{tabular}{|c|c|c|c|c|c|c|}
\hline $\begin{array}{l}\text { among primary care } \\
\text { practices a randomized } \\
\text { clinical trial. JAMA, } \\
315(6), 562-570 \text {. }\end{array}$ & & & $\begin{array}{l}\text { selected. The } \\
\text { control group did } \\
\text { not receive these } \\
\text { guidelines when } \\
\text { selecting the } \\
\text { above diagnosis. } \\
\text { Both groups did } \\
\text { receive education } \\
\text { on education on } \\
\text { antibiotic } \\
\text { prescribing. }\end{array}$ & & $\begin{array}{c}\text { antibiotic } \\
\text { prescribing. }\end{array}$ & \\
\hline $\begin{array}{l}\text { O’Sullivan, J.W., } \\
\text { Harvey, R.T., } \\
\text { Glasziou, P.P., \& } \\
\text { McCullough, A., } \\
\text { (2016). Written } \\
\text { information for } \\
\text { patients (or parents of } \\
\text { child patients) to } \\
\text { reduce the use of } \\
\text { antibiotics for acute } \\
\text { upper respiratory } \\
\text { tract infections in } \\
\text { primary care. } \\
\text { Cochrane Library, } 11 . \\
\text { Doi:10.1002/14651858 }\end{array}$ & $\begin{array}{l}\text { Cluster } \\
\text { randomized } \\
\text { control trial } \\
\text { Evidence } \\
\text { Level: } 2 \\
\text { Quality: B }\end{array}$ & $\begin{array}{l}827 \\
\text { participants in } \\
\text { primary care } \\
\text { setting. }\end{array}$ & $\begin{array}{l}\text { The intervention } \\
\text { consisted of } \\
\text { patients/parents } \\
\text { receiving } \\
\text { education } \\
\text { material about } \\
\text { antibiotics either } \\
\text { before or during } \\
\text { patient visits and } \\
\text { the control } \\
\text { received no } \\
\text { information. }\end{array}$ & $\begin{array}{l}\text { No theoretical } \\
\text { framework }\end{array}$ & $\begin{array}{l}\text { The intervention } \\
\text { groups showed a } \\
\text { decrease in } \\
\text { antibiotics } \\
\text { prescribed when } \\
\text { compared to the } \\
\text { control group. } \\
\text { No major } \\
\text { difference was } \\
\text { noted if the } \\
\text { educational } \\
\text { material is given } \\
\text { before or during } \\
\text { the visit. }\end{array}$ & $\begin{array}{l}\text { When educational material is } \\
\text { given to patients/parents there } \\
\text { is a reduction in the amount } \\
\text { of antibiotics prescribed for } \\
\text { acute respiratory illnesses } \\
\text { when compared to not giving } \\
\text { educational material. There } \\
\text { was not much difference in } \\
\text { the reduction of antibiotics } \\
\text { prescribed when timing of } \\
\text { sharing the educational } \\
\text { material was before or during } \\
\text { the patient visits. }\end{array}$ \\
\hline $\begin{array}{l}\text { Wei, X., Zhang, Z., } \\
\text { Walley, J., Hicks, J., } \\
\text { Zeng, J., Deng, S. } \\
\ldots \ldots . ., \text { \& Lin, M. } \\
\text { (2017). Effects of } \\
\text { training and } \\
\text { educational } \\
\text { interventions for } \\
\text { physicians and }\end{array}$ & $\begin{array}{l}\text { Cluster } \\
\text { randomized } \\
\text { control trial } \\
\text { Evidence } \\
\text { Level: } 1 \\
\text { Quality: B }\end{array}$ & $\begin{array}{l}25 \text { eligible } \\
\text { hospitals. All } \\
\text { randomly } \\
\text { assigned, 12- } \\
\text { placed in the } \\
\text { intervention } \\
\text { group and 13- } \\
\text { placed in the } \\
\text { control group. }\end{array}$ & $\begin{array}{l}\text { The } \\
\text { intervention } \\
\text { was } \\
\text { implemented in } \\
3 \text { internal pilot } \\
\text { clusters. The } \\
\text { intervention } \\
\text { group received } \\
\text { clinical }\end{array}$ & $\begin{array}{l}\text { No theoretical } \\
\text { framework }\end{array}$ & $\begin{array}{l}\text { The intervention } \\
\text { group showed a } \\
\text { large decrease in } \\
\text { the amount of } \\
\text { antibiotics } \\
\text { prescribed for } \\
\text { upper respiratory } \\
\text { infections with a }\end{array}$ & $\begin{array}{l}\text { The implementation of } \\
\text { clinical guidelines } \\
\text { accompanied by monthly peer } \\
\text { reviews has a large effect on } \\
\text { the reduction of unwarranted } \\
\text { antibiotic prescribing for } \\
\text { upper respiratory tract } \\
\text { infections in the pediatric } \\
\text { outpatient settings in China }\end{array}$ \\
\hline
\end{tabular}




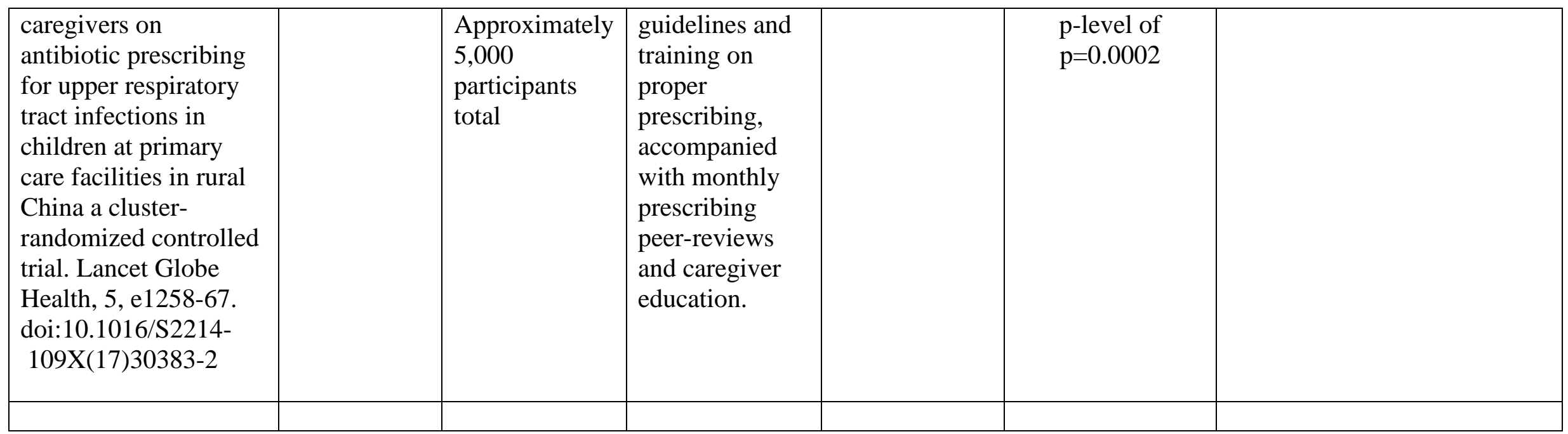


Appendix $\mathbf{H}$

Summary of Systematic Reviews (SR)

\begin{tabular}{|c|c|c|c|c|c|c|c|}
\hline Citation & $\begin{array}{l}\text { Quality } \\
\text { Grade }\end{array}$ & Question & Search Strategy & $\begin{array}{l}\text { Inclusion/ } \\
\text { Exclusion Criteria }\end{array}$ & $\begin{array}{l}\text { Data Extraction and } \\
\text { Analysis }\end{array}$ & Key Findings & $\begin{array}{l}\text { Usefulness/Recommend } \\
\text { ation/ } \\
\text { Implications }\end{array}$ \\
\hline $\begin{array}{l}\text { Drekonja, D., } \\
\text { Filice, G., } \\
\text { Greer, N., } \\
\text { Olson, A., } \\
\text { MacDDonald, } \\
\text { R., Rutks, I., } \\
\text { \& Wilt, T., } \\
\text { (2015). } \\
\text { Antimicrobial } \\
\text { stewardship in } \\
\text { outpatient } \\
\text { settings: a } \\
\text { systematic } \\
\text { review. } \\
\text { Infection } \\
\text { Control } \\
\text { Hospital } \\
\text { Epidemiology } \\
\text { 36(2), 142- } \\
152 . \\
\text { Doi:10.1017/i } \\
\text { ce.2014.41 } \\
\end{array}$ & 3 & $\begin{array}{l}\text { Assess the effect } \\
\text { antimicrobial } \\
\text { stewardship } \\
\text { programs have on } \\
\text { prescribing, } \\
\text { patients, microbial } \\
\text { outcomes, and cost } \\
\text { in outpatient } \\
\text { settings }\end{array}$ & $\begin{array}{l}\text { Time frame was } \\
\text { limited to 2000- } \\
\text { November 2013. } \\
\text { Medline, } \\
\text { Cochrane Library, } \\
\text { and relevant study } \\
\text { reference lists } \\
\text { were researched. }\end{array}$ & $\begin{array}{l}\text { Inclusion included, } \\
\text { English speaking, } \\
\text { stewardship programs, } \\
\text { outpatient settings. } \\
\text { Exclusions were } \\
\text { patient population that } \\
\text { were not similar to the } \\
\text { United States. } \\
50 \text { studies were chosen } \\
\text { for inclusion }\end{array}$ & $\begin{array}{l}\text { Data extraction } \\
\text { focused on study } \\
\text { characteristics } \\
\text { and outcomes } \\
\text { such as patient } \\
\text { prescribing, } \\
\text { microbials, cost } \\
\text { and harm }\end{array}$ & $\begin{array}{l}\text { Antimicrobial } \\
\text { stewardship programs } \\
\text { in outpatient settings } \\
\text { show a small amount of } \\
\text { improvement in } \\
\text { antimicrobial } \\
\text { prescribing. With } \\
\text { outcomes dependent on } \\
\text { intervention types. } \\
\text { Decrease in prescribing } \\
\text { also resulted in } \\
\text { decrease overall costs } \\
\text { as well. No harm was } \\
\text { noted. Microbial } \\
\text { outcomes were not } \\
\text { reported. }\end{array}$ & $\begin{array}{l}\text { Implementation of } \\
\text { antimicrobial } \\
\text { stewardship programs } \\
\text { does help to decrease } \\
\text { antibiotic prescription } \\
\text { rates. However, the } \\
\text { level of effectiveness } \\
\text { will greatly depend } \\
\text { on choosing the most } \\
\text { effective stewardship } \\
\text { program in order to } \\
\text { maximize the } \\
\text { program outcome } \\
\text { effect. }\end{array}$ \\
\hline $\begin{array}{l}\text { Holstiege, J., } \\
\text { Mathes, T., \& } \\
\text { Pieper, D. } \\
\text { (2015) Effects } \\
\text { of computer- } \\
\text { aided clinical } \\
\text { decision } \\
\text { support } \\
\end{array}$ & $\beta$ & $\begin{array}{l}\text { Do computer aided } \\
\text { clinical decision } \\
\text { support systems } \\
\text { help to improve } \\
\text { antibiotic } \\
\text { prescribing for } \\
\text { primary care } \\
\text { providers }\end{array}$ & $\begin{array}{l}\text { Literature search } \\
\text { utilizing Medline } \\
\text { and Embase was } \\
\text { conducted up to } \\
\text { November } 2013 \text {. }\end{array}$ & $\begin{array}{l}\text { Included all studies } \\
\text { that were outpatient } \\
\text { randomized controlled } \\
\text { trials or cluster- } \\
\text { randomized trials that } \\
\text { utilized computer } \\
\text { aided guidelines to }\end{array}$ & $\begin{array}{l}\text { Data extracted } \\
\text { included study } \\
\text { design, setting, } \\
\text { condition } \\
\text { antibiotics were } \\
\text { prescribed, } \\
\text { intervention and } \\
\text { control group, }\end{array}$ & $\begin{array}{l}\text { Computer aided clinic } \\
\text { support systems were } \\
\text { more likely to improve } \\
\text { antibiotic prescribing } \\
\text { by primary providers } \\
\text { compared to those who } \\
\text { had no assistance. }\end{array}$ & $\begin{array}{l}\text { Clinical guidelines } \\
\text { that are imbedded } \\
\text { into the computer } \\
\text { system can greatly } \\
\text { improve primary } \\
\text { providers antibiotic } \\
\text { prescribing. }\end{array}$ \\
\hline
\end{tabular}




\begin{tabular}{|c|c|c|c|c|c|c|c|}
\hline Citation & $\begin{array}{l}\text { Quality } \\
\text { Grade }\end{array}$ & Question & Search Strategy & $\begin{array}{l}\text { Inclusion/ } \\
\text { Exclusion Criteria }\end{array}$ & $\begin{array}{l}\text { Data Extraction and } \\
\text { Analysis }\end{array}$ & Key Findings & $\begin{array}{l}\text { Usefulness/Recommend } \\
\text { ation/ } \\
\text { Implications }\end{array}$ \\
\hline $\begin{array}{l}\text { systems in } \\
\text { improving } \\
\text { antibiotic } \\
\text { prescribing by } \\
\text { primary care } \\
\text { providers: a } \\
\text { systematic } \\
\text { review. } \\
\text { Journal of } \\
\text { American } \\
\text { Medical } \\
\text { Information } \\
\text { Association, } \\
\text { 22, 236-242. }\end{array}$ & & & & \begin{tabular}{l||} 
assist with antibiotic \\
prescribing. \\
Exclusion non \\
computer aided \\
clinical decision \\
support, studies that \\
analyzed antibiotics \\
amongst other drugs, \\
non-outpatient settings
\end{tabular} & $\begin{array}{l}\text { sample size, } \\
\text { number of } \\
\text { patients/visits, } \\
\text { outcome, and } \\
\text { results. Analyzed } \\
\text { the number of } \\
\text { antibiotics } \\
\text { prescribed. }\end{array}$ & & \\
\hline
\end{tabular}


Appendix I

\section{Antibiotic Stewardship Change Project SWOT Analysis}

\begin{tabular}{|c|c|}
\hline Strengths & Weaknesses \\
\hline $\begin{array}{l}\text { - } \quad \text { executive leader buy-in } \\
\text { - } \text { the ease of implementation } \\
\text { - } \quad \text { very little demand in outside resources } \\
\text { - } \quad \text { strong desire by all involved to achieve national } \\
\text { benchmarks }\end{array}$ & $\begin{array}{l}\text { - unhappy patients when not receiving their desired } \\
\text { treatment of choice } \\
\text { - } \text { resistance of medical providers to utilize clinical } \\
\text { guideline to guide their medical decision making } \\
\text { - increase in time spent with each patient }\end{array}$ \\
\hline Opportunities & Threats \\
\hline $\begin{array}{l}\text { consistent messaging to clinical providers regarding the } \\
\text { utilization of clinical guidelines for all associated } \\
\text { treatment modalities } \\
\text { providing providers with educational sessions on how to } \\
\text { have confident conversation with patients when pushback } \\
\text { may be experienced as a result of this practice change }\end{array}$ & $\begin{array}{l}\text { - inability to obtain an adequate amount of "Be Smart" } \\
\text { pamphlets } \\
\text { - patient's unwillingness to review the educational } \\
\text { pamphlet }\end{array}$ \\
\hline
\end{tabular}




\section{Appendix J}

\section{Project Schedule}

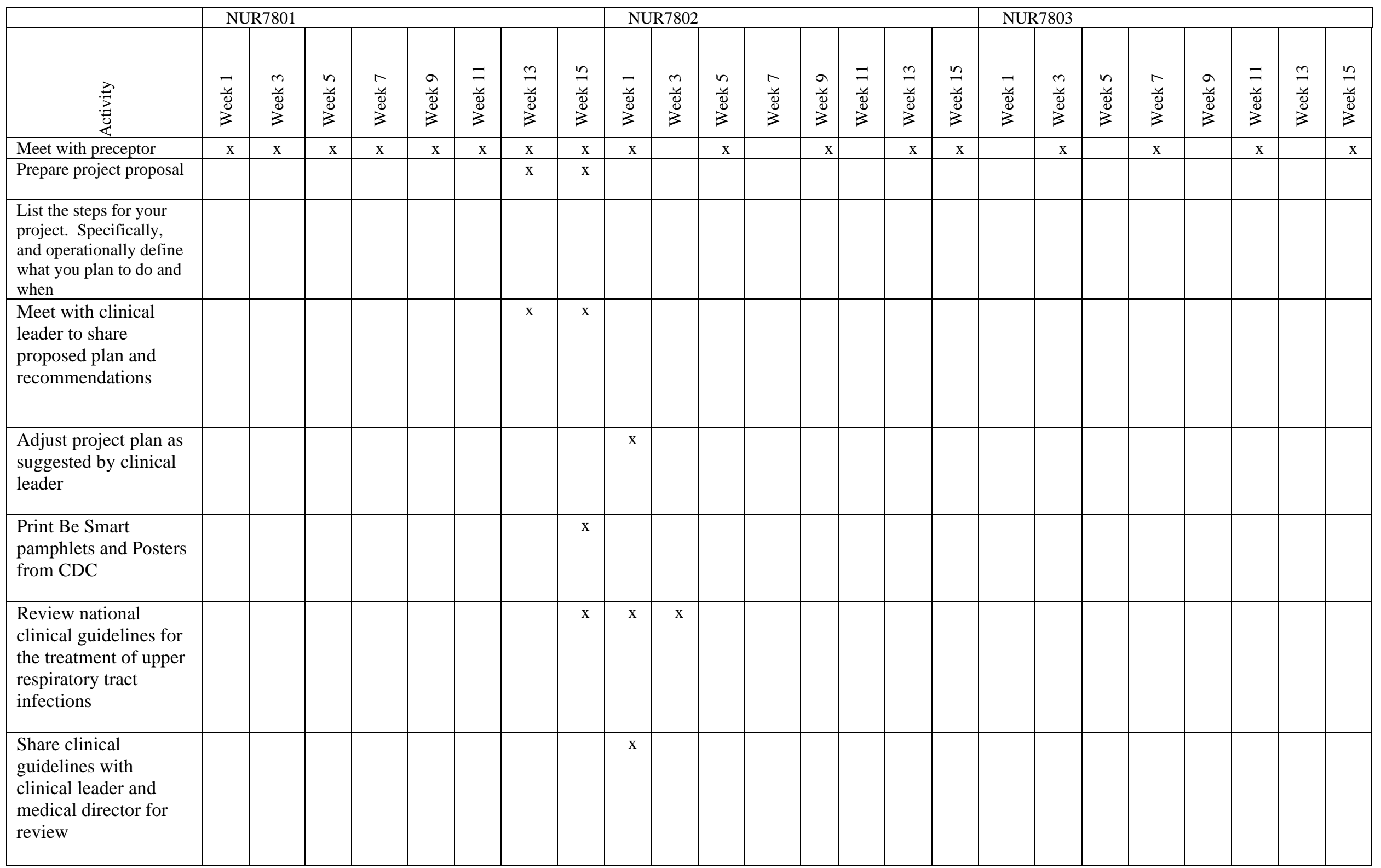




\begin{tabular}{|c|c|c|c|c|c|c|c|c|c|c|c|c|c|c|c|c|c|c|c|c|c|c|c|c|}
\hline & & 780 & & & & & & & & 780 & & & & & & & & 803 & & & & & & \\
\hline 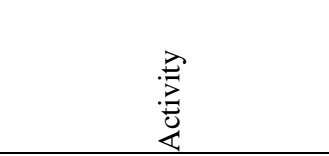 & $\frac{7}{\frac{\pi}{2}}$ & $\begin{array}{l}m \\
\frac{1}{2} \\
3 \\
3\end{array}$ & $\begin{array}{l}n \\
\frac{n}{0} \\
3 \\
3\end{array}$ & $\frac{5}{3}$ & $\begin{array}{l}\frac{a}{2} \\
\frac{1}{3} \\
3\end{array}$ & $\begin{array}{l}= \\
\bar{y} \\
\frac{0}{3}\end{array}$ & $\frac{m}{\frac{n}{d}}$ & $\frac{n}{\frac{n}{8}}$ & $\frac{7}{y}$ & $\begin{array}{l}m \\
\text { 范 } \\
3 \\
3\end{array}$ & $\begin{array}{l}n \\
\frac{1}{2} \\
3 \\
3\end{array}$ & $\frac{5}{\frac{1}{0}}$ & $\begin{array}{l}\frac{a}{0} \\
\frac{0}{3} \\
3\end{array}$ & $\begin{array}{l}= \\
\frac{y}{d} \\
\frac{0}{3}\end{array}$ & $\begin{array}{l}\frac{m}{2} \\
\frac{y}{0} \\
\frac{0}{3}\end{array}$ & $\begin{array}{l}n \\
\frac{n}{0} \\
\frac{\pi}{3}\end{array}$ & $\frac{7}{3}$ & $\begin{array}{l}n \\
\frac{n}{0} \\
3 \\
3\end{array}$ & $\begin{array}{l}n \\
\frac{1}{8} \\
3 \\
3\end{array}$ & $\begin{array}{l}\frac{1}{d} \\
\frac{1}{3} \\
3\end{array}$ & $\begin{array}{l}a \\
\text { vi } \\
3 \\
3\end{array}$ & $\begin{array}{l}= \\
\frac{y}{0} \\
3\end{array}$ & $\begin{array}{l}\frac{m}{4} \\
\frac{4}{0} \\
3\end{array}$ & $\begin{array}{l}\frac{n}{2} \\
\frac{y}{d} \\
\frac{d}{3}\end{array}$ \\
\hline $\begin{array}{l}\text { Create clinical smart } \\
\text { set to be utilized when } \\
\text { treating upper } \\
\text { respiratory tract } \\
\text { infections }\end{array}$ & & & & & & & & & $\mathrm{X}$ & & & & & & & & & & & & & & & \\
\hline $\begin{array}{l}\text { Under the direction of } \\
\text { clinical leader identify } \\
\text { which clinic will take } \\
\text { part in project change }\end{array}$ & & & & & & & & & $\mathrm{X}$ & & & & & & & & & & & & & & & \\
\hline $\begin{array}{l}\text { Prepare antibiotic } \\
\text { stewardship } \\
\text { presentation for } \\
\text { meeting for providers } \\
\text { that will be } \\
\text { participants of practice } \\
\text { change }\end{array}$ & & & & & & & & & $\mathrm{X}$ & & & & & & & & & & & & & & & \\
\hline $\begin{array}{l}\text { Conduct historical } \\
\text { review of average } \\
\text { number of antibiotics } \\
\text { prescribed for upper } \\
\text { respiratory tract } \\
\text { infections for the six- } \\
\text { week intervention } \\
\text { timeframe year prior }\end{array}$ & & & & & & & & & $\bar{x}$ & $\mathrm{x}$ & & & & & & & & & & & & & & \\
\hline $\begin{array}{l}\text { Conduct meeting sharing } \\
\text { presentation and current } \\
\text { rate of prescribing; } \\
\text { introduce planned } \\
\text { practice change. }\end{array}$ & & & & & & & & & $\mathrm{x}$ & & & & & & & & & & & & & & & \\
\hline $\begin{array}{l}\text { Hold small educational } \\
\text { sessions reviewing the } \\
\text { new clinical guidelines } \\
\text { to be used as well as } \\
\text { familiarizing providers }\end{array}$ & & & & & & & & & & $\mathrm{x}$ & & & & & & & & & & & & & & \\
\hline
\end{tabular}




\begin{tabular}{|c|c|c|c|c|c|c|c|c|c|c|c|c|c|c|c|c|c|c|c|c|c|c|c|c|}
\hline & & 7801 & & & & & & & & 780 & & & & & & & & 803 & & & & & & \\
\hline 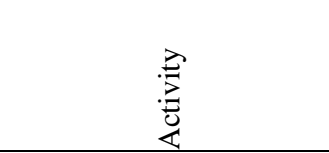 & $\frac{\sqrt{4}}{3}$ & $\frac{n}{3}$ & $\begin{array}{l}n \\
\frac{4}{0} \\
\frac{d}{3}\end{array}$ & $\frac{5}{0}$ & $\frac{a}{\frac{1}{0}}$ & $\begin{array}{l}= \\
\frac{y}{0} \\
3\end{array}$ & $\begin{array}{l}\frac{m}{2} \\
\frac{\pi}{0} \\
3\end{array}$ & $\frac{n}{\frac{n}{8}}$ & $\begin{array}{l}\bar{y} \\
\frac{0}{3} \\
3\end{array}$ & $\frac{n}{u}$ & $\begin{array}{l}n \\
\frac{y}{0} \\
3 \\
3\end{array}$ & $\frac{5}{y}$ & $\begin{array}{l}\frac{a}{u} \\
\frac{u}{z}\end{array}$ & $\begin{array}{l}= \\
\frac{y}{8} \\
3 \\
3\end{array}$ & $\begin{array}{l}\frac{m}{2} \\
\frac{y}{d} \\
\frac{d}{3}\end{array}$ & $\begin{array}{l}n \\
\frac{1}{3} \\
\frac{1}{3}\end{array}$ & $\frac{\bar{y}}{3}$ & $\frac{n}{3}$ & $\begin{array}{l}n \\
\frac{y}{d} \\
z \\
z\end{array}$ & $\frac{\pi}{3}$ & $\begin{array}{l}a \\
\frac{u}{0} \\
z\end{array}$ & $\begin{array}{l}= \\
\frac{y}{d} \\
3\end{array}$ & $\frac{n}{\frac{n}{2}}$ & $\frac{n}{\frac{n}{d}}$ \\
\hline $\begin{array}{l}\text { with the patient Be Smart } \\
\text { pamphlets }\end{array}$ & & & & & & & & & & & & & & & & & & & & & & & & \\
\hline $\begin{array}{l}\text { Hold Q \& A sessions for } \\
\text { those providers who are } \\
\text { requesting additional } \\
\text { information/ resource } \\
\text { prior to project } \\
\text { implementation. }\end{array}$ & & & & & & & & & $\mathrm{X}$ & & & & & & & & & & & & & & & \\
\hline $\begin{array}{l}\text { Deliver all educational } \\
\text { material to the } \\
\text { pediatric clinic }\end{array}$ & & & & & & & & & $\mathrm{x}$ & & & & & & & & & & & & & & & \\
\hline Project go live date & & & & & & & & & & & $\mathrm{x}$ & & & & & & & & & & & & & \\
\hline $\begin{array}{l}\text { Check in with } \\
\text { providers regarding } \\
\text { questions or concerns }\end{array}$ & & & & & & & & & & & $\mathrm{x}$ & $\mathrm{x}$ & & & & & & & & & & & & \\
\hline $\begin{array}{l}\text { Review current rate of } \\
\text { prescribing for upper } \\
\text { respiratory tract } \\
\text { infections }\end{array}$ & & & & & & & & & & & & $\mathrm{x}$ & & $\mathrm{x}$ & $\mathrm{x}$ & $\mathrm{x}$ & & & & & & & & \\
\hline $\begin{array}{l}\text { Evaluate the providers } \\
\text { concerns and compare } \\
\text { to see if may have } \\
\text { impact on current rate } \\
\text { of prescribing }\end{array}$ & & & & & & & & & & & & $\mathrm{x}$ & $\mathrm{x}$ & & & & & & & & & & & \\
\hline
\end{tabular}




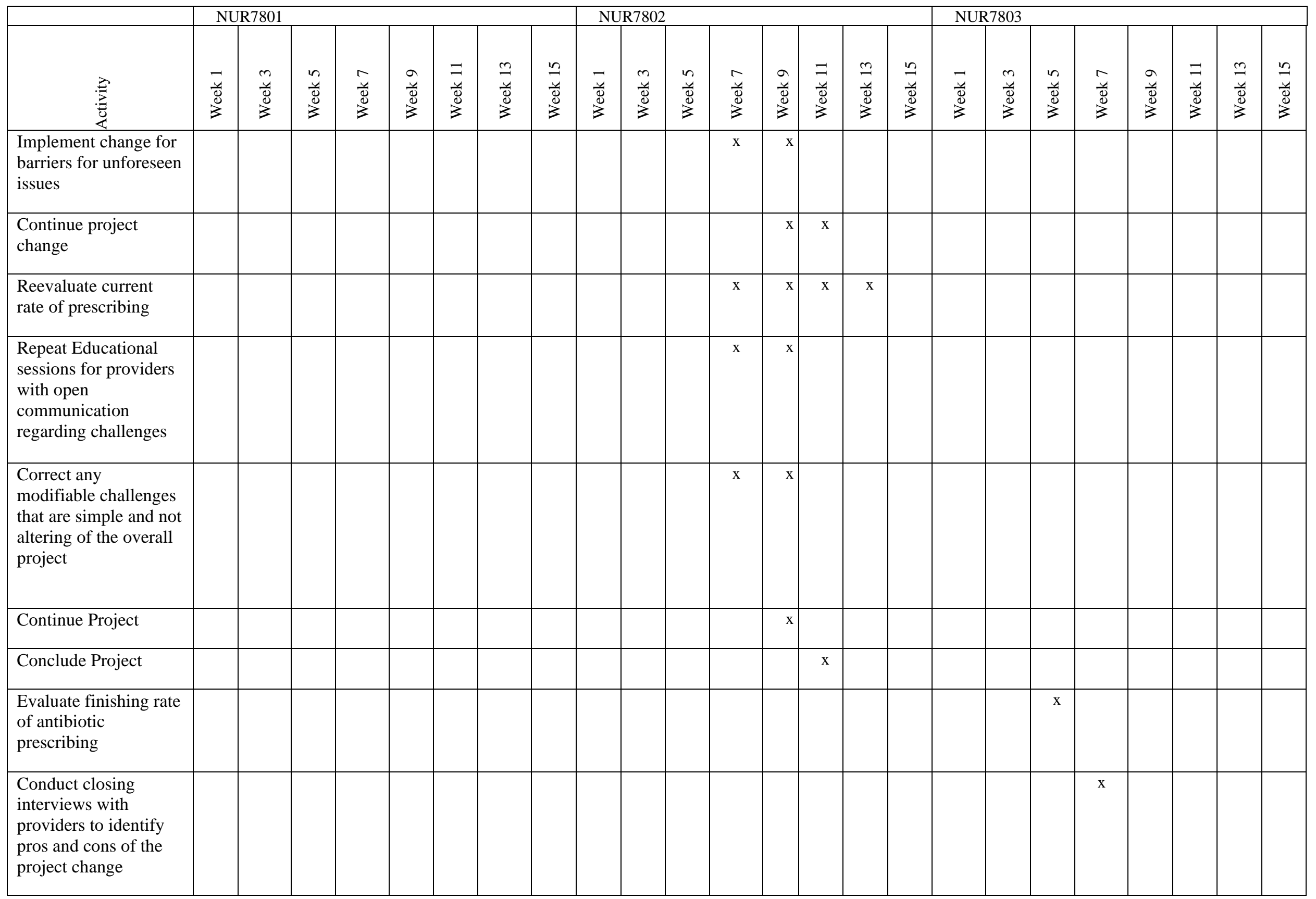




\begin{tabular}{|c|c|c|c|c|c|c|c|c|c|c|c|c|c|c|c|c|c|c|c|c|c|c|c|c|}
\hline & & 7801 & & & & & & & & 27802 & & & & & & & & 803 & & & & & & \\
\hline$\stackrel{\vec{z}}{\vec{Z}}$ & $\begin{array}{l}\bar{y} \\
\frac{\pi}{3} \\
z\end{array}$ & $\begin{array}{l}\frac{m}{\tilde{J}} \\
\stackrel{\tilde{d}}{3}\end{array}$ & $\begin{array}{l}n \\
\frac{n}{0} \\
3\end{array}$ & $\begin{array}{l}\bar{y} \\
\frac{u}{0} \\
3\end{array}$ & $\begin{array}{l}a \\
\frac{u}{0} \\
3\end{array}$ & $\begin{array}{l}= \\
\bar{J} \\
3\end{array}$ & $\begin{array}{l}\frac{m}{\vec{u}} \\
\frac{\vec{d}}{3}\end{array}$ & $\begin{array}{l}n \\
\frac{n}{0} \\
z\end{array}$ & $\begin{array}{l}\vec{u} \\
\frac{\vec{d}}{3}\end{array}$ & $\begin{array}{l}m \\
\text { ü } \\
\dot{b}\end{array}$ & $\begin{array}{l}n \\
\frac{u}{0} \\
3\end{array}$ & $\begin{array}{l}\bar{y} \\
\frac{u}{0} \\
3\end{array}$ & $\begin{array}{l}a \\
\ddot{u} \\
\vec{z}\end{array}$ & $\begin{array}{l}z \\
\frac{\vec{u}}{d} \\
z\end{array}$ & $\begin{array}{l}m \\
\frac{n}{d} \\
3\end{array}$ & $\begin{array}{l}n \\
\frac{n}{d} \\
3\end{array}$ & $\begin{array}{l}\bar{y} \\
\frac{\pi}{0} \\
3\end{array}$ & $\begin{array}{l}\frac{m}{u} \\
\frac{\pi}{3} \\
z\end{array}$ & $\begin{array}{l}n \\
\stackrel{y}{u} \\
3 \\
3\end{array}$ & $\begin{array}{l}i \\
\frac{u}{0} \\
3\end{array}$ & $\begin{array}{l}a \\
\frac{\vec{d}}{d} \\
\vec{z}\end{array}$ & $\begin{array}{l}= \\
\text { " } \\
\text { ju }\end{array}$ & $\begin{array}{l}\frac{m}{n} \\
\frac{\pi}{D} \\
3\end{array}$ & $\begin{array}{l}\frac{n}{3} \\
\frac{1}{0} \\
3\end{array}$ \\
\hline $\begin{array}{l}\text { Conduct final meeting } \\
\text { presenting the } \\
\text { outcome results of the } \\
\text { practice change }\end{array}$ & & & & & & & & & & & & & & & & & & & & & & $\mathrm{x}$ & & \\
\hline
\end{tabular}

Legend: $\mathrm{x}$ - denotes the timeframe an activity will be completed in 


\section{Appendix K}

Measures to Improve Antibiotic Prescribing

\begin{tabular}{|c|c|c|c|}
\hline Measures & Actions & Goals & $\begin{array}{c}\text { Statistical Test/ } \\
\text { Data Type }\end{array}$ \\
\hline Outcome Measures & $\begin{array}{l}\text { The retrospective } \\
\text { number of patients } \\
\text { with ARI's that } \\
\text { receive antibiotic } \\
\text { upon discharge. } \\
\text { Numerator being the } \\
\text { number of patients } \\
\text { with ARI's that } \\
\text { receive an antibiotic. } \\
\text { Denominator being } \\
\text { the total number of } \\
\text { patients seen and } \\
\text { diagnosed with ARI } \\
\text { in the correlating } \\
\text { six-week timeframe } \\
\text { the year prior to } \\
\text { intervention. }\end{array}$ & $\mathrm{n} / \mathrm{a}$ & $\begin{array}{l}\text { Discrete Count/ } \\
\text { Mean }\end{array}$ \\
\hline Outcome Measures & $\begin{array}{l}\text { The number of } \\
\text { patients with ARI's } \\
\text { that receive } \\
\text { antibiotic upon } \\
\text { discharge during } \\
\text { intervention. } \\
\text { Numerator being the } \\
\text { number of patients } \\
\text { with ARI's that } \\
\text { receive an antibiotic. } \\
\text { Denominator being } \\
\text { the total number of } \\
\text { patients seen and } \\
\text { diagnosed with } \\
\text { ARI's. }\end{array}$ & Reduction of $>15 \%$ & $\begin{array}{l}\text { Discrete Count/ } \\
\text { Mean; paired t } \\
\text { test for mean of } \\
\text { score difference }\end{array}$ \\
\hline
\end{tabular}




\begin{tabular}{|c|c|c|c|}
\hline Outcome Measures & $\begin{array}{l}\text { Provider attitude } \\
\text { and beliefs towards } \\
\text { antibiotic } \\
\text { stewardship. } \\
\text { Provider pre- and } \\
\text { post-implementation } \\
\text { survey. Higher } \\
\text { scores associated } \\
\text { with more favorable } \\
\text { opinions. }\end{array}$ & Increase by $20 \%$ & $\begin{array}{l}\text { Continuous Data/ } \\
\mathrm{X} 2\end{array}$ \\
\hline Balance Measures & $\begin{array}{l}\text { Patients resistance } \\
\text { to not being } \\
\text { prescribed an } \\
\text { antibiotic. } \\
\text { Providers will report } \\
\text { low incidence of } \\
\text { patient resistance to } \\
\text { new prescribing } \\
\text { practices }\end{array}$ & $\begin{array}{l}\text { Less than } 5 \% \\
\text { increase in providers } \\
\text { reporting patient } \\
\text { resistance }\end{array}$ & $\begin{array}{l}\text { Continuous Data/ } \\
\mathrm{X} 2\end{array}$ \\
\hline Process Measures & $\begin{array}{l}\text { Percent of } \\
\text { providers educated } \\
\text { on clinical } \\
\text { guidelines. } \\
\text { Total number of } \\
\text { providers to be } \\
\text { trained on clinical } \\
\text { guideline. }\end{array}$ & $100 \%$ & $\begin{array}{l}\text { Continuous/ } \\
\mathrm{X} 2\end{array}$ \\
\hline Financial Measures & $\begin{array}{l}\text { Cost of } \\
\text { Implementation. } \\
\text { Total cost to } \\
\text { implement project. }\end{array}$ & $<\$ 900$ & $\mathrm{X} 2$ \\
\hline
\end{tabular}

